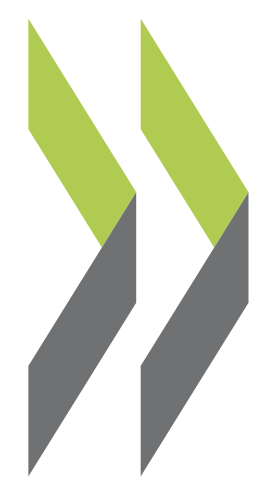

OECD Economics Department Working Papers No. 963

Promoting Social Cohesion Randall S. Jones, Satoshi Urasawa 


\section{Unclassified}

ECO/WKP(2012)40

Organisation de Coopération et de Développement Économiques

Organisation for Economic Co-operation and Development

05-Jun-2012

ECONOMICS DEPARTMENT

English - Or. English

PROMOTING SOCIAL COHESION IN KOREA

ECONOMICS DEPARTMENT WORKING PAPERS No. 963

by Randall S. Jones and Satoshi Urasawa

All Economics Department Working Papers are available through OECD's Internet website at www.oecd.org/eco/workingpapers

JT03322994

Complete document available on OLIS in its original format

This document and any map included herein are without prejudice to the status of or sovereignty over any territory, to the delimitation of international frontiers and boundaries and to the name of any territory, city or area. 


\section{ABSTRACT/RÉSUMÉ \\ Promoting social cohesion in Korea}

Korea faces the challenge of reversing rising inequality while sustaining robust economic growth. Welltargeted increases in Korea's low level of social spending are needed to fill holes in the safety net, especially for the elderly. The development of social security depends on closing gaps in coverage, which are due in part to labour market dualism. Dualism creates serious equity concerns, as non-regular workers face significantly lower wages, precarious jobs, less coverage by social security and less training. A comprehensive approach is required to break down dualism, including reduced employment protection for regular workers, improved social insurance coverage for non-regular workers and expanded training of non-regular workers. Education reforms are also needed to promote inclusive growth, notably by: i) improving the access of low-income children to high-quality early childhood education and care; ii) reducing reliance on private tutoring, notably at hagwons; and iii) expanding income-contingent loans to tertiary students.

This Working Paper relates to the 2012 OECD Economic Survey of Korea (www.oecd.org/eco/surveys/Korea).

JEL classification: D6, H5, I2, J3, O53.

Keywords: Korea; Korean economy; income inequality; relative poverty; social spending; Basic Livelihood Security Programme; earned income tax credit; Basic Old-Age Pension; labour market dualism; non-regular workers; education; ECEC; childcare; hagwons; student loans; service sector.

\section{Promouvoir la cohésion sociale en Corée}

La Corée doit s'attacher à inverser le creusement des inégalités tout en soutenant une croissance économique vigoureuse. Des hausses ciblées des dépenses sociales actuellement peu élevées de la Corée sont nécessaires pour combler les lacunes du filet de protection sociale, en particulier pour les personnes âgées. Pour développer la sécurité sociale, il faut combler les lacunes de la couverture, lesquelles résultent en partie du dualisme du marché du travail. Ce dualisme engendre de graves problèmes d'équité, car les travailleurs temporaires perçoivent des salaires nettement inférieurs, occupent des emplois précaires, bénéficient d'une couverture sociale plus limitée et d'un moindre accès à la formation. Il faut adopter une approche globale pour briser le dualisme, notamment en réduisant la protection de l'emploi pour les travailleurs réguliers, en améliorant la couverture sociale pour les travailleurs temporaires et en développant les formations offertes à ces travailleurs. Des réformes de l'éducation sont également requises pour promouvoir une croissance inclusive, notamment: i) en améliorant l'accès des enfants issus de milieux pauvres à des services d'éducation et d'accueil des jeunes enfants de qualité; ii) en réduisant le recours au tutorat privé, notamment aux hagwons; et iii) en accordant aux étudiants de l'enseignement supérieur davantage de prêts remboursables en fonction de leurs revenus futurs.

Ce Document de travail se rapporte à l'Étude économique de l'OCDE de la Corée, 2012 (www.oecd.org/eco/etudes/corée).

Classification JEL : D6, H5, I2, J3, O53.

Mots clés: Corée; économie coréene; inégalités de revenu; pauvreté relative; dépenses sociales; Programme de garantie du minimum de subsistance ; crédit d'impôt sur les revenus du travail; dualisme du marché du travail ; travailleurs non réguliers ; système éducatif ; EAJE ; hagwons.

\section{(C) OECD (2012)}

You can copy, download or print OECD content for your own use, and you can include excerpts from OECD publications, databases and multimedia products in your own documents, presentations, blogs, websites and teaching materials, provided that suitable acknowledgment of OECD as source and copyright owner is given. All requests for commercial use and translation rights should be submitted to rights@oecd.org 


\section{TABLE OF CONTENTS}

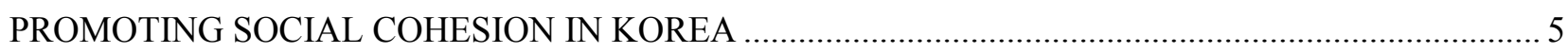

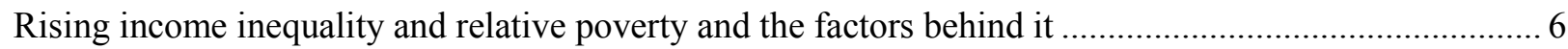

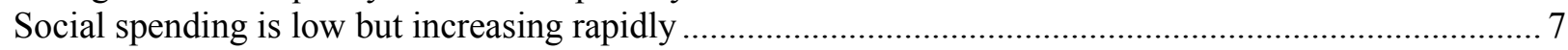

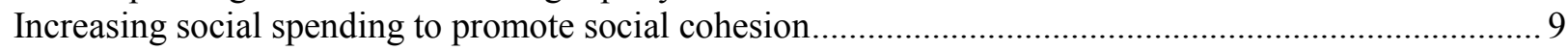

The Basic Livelihood Security Programme (BLSP) ......................................................................... 10

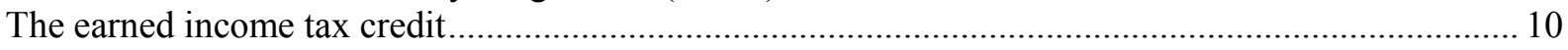

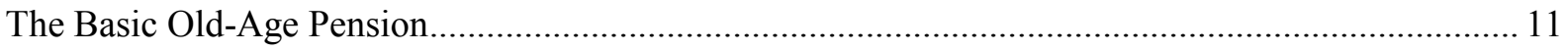

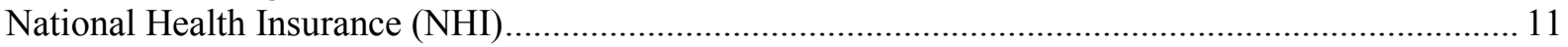

Improving participation in social insurance programmes................................................................... 12

Labour market reforms to promote social cohesion by breaking down dualism..................................... 13

Factors explaining the high level of labour market dualism........................................................... 14

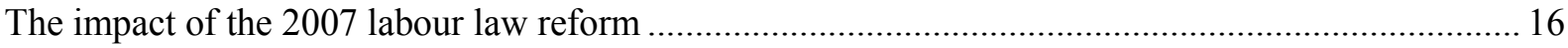

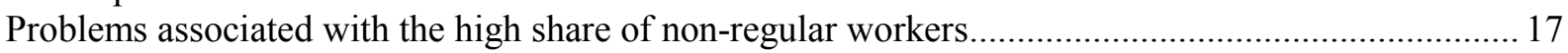

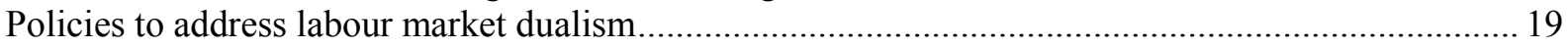

Reforms in the education system to promote social cohesion.............................................................. 21

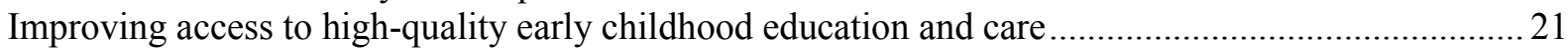

Reducing the reliance on private tutoring: addressing the issue of hagwons .......................................23

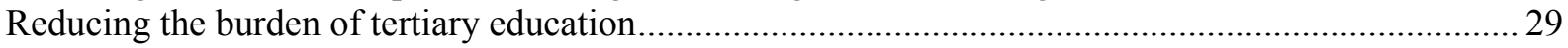

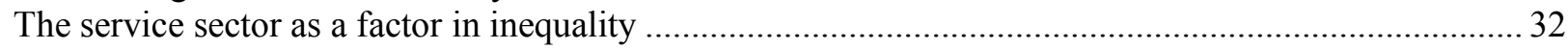

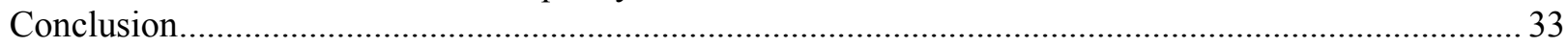

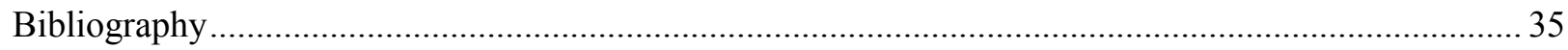

\section{Tables}

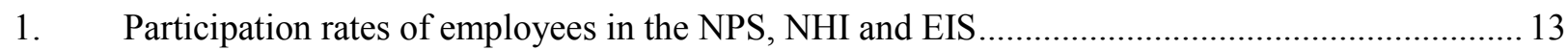

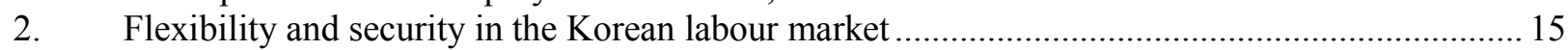

3. Reasons given by firms for hiring non-regular workers ...................................................... 15

4. Reasons given by non-regular workers for accepting non-regular employment......................... 16

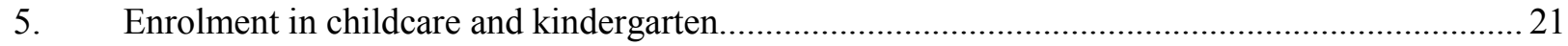

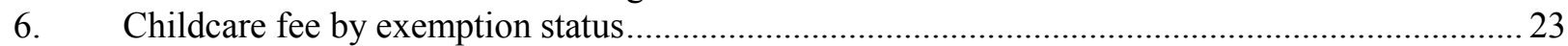

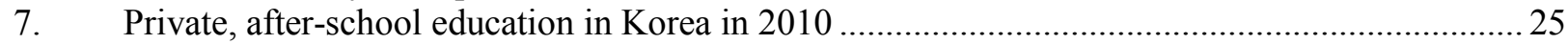

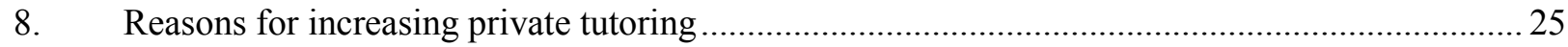

9. Participation and spending in private tutoring rises with academic performance ........................2 26

10. Policies that would reduce spending on private tutoring ...........................................................2

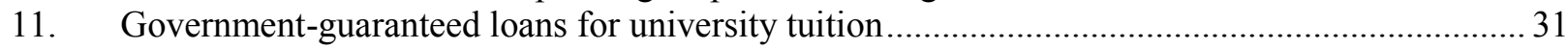

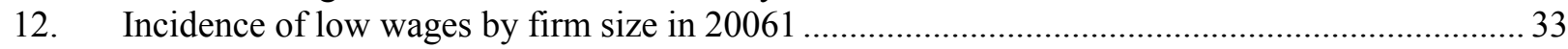




\section{Figures}

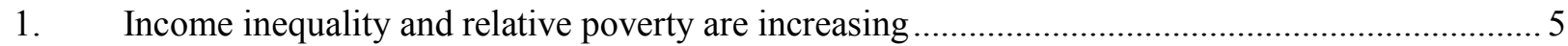

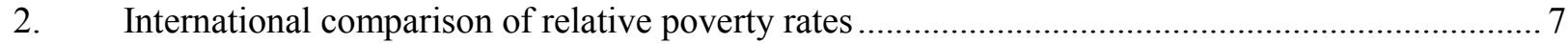

3. International comparison of public social spending ............................................................... 8

4. The composition of public social spending in Korea compared to the OECD average ................. 9

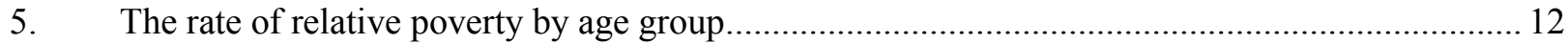

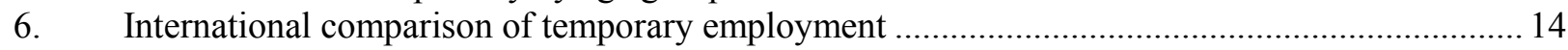

7. Poverty rate among working-age population in 2006 by employment status ............................ 18

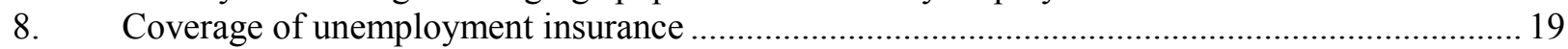

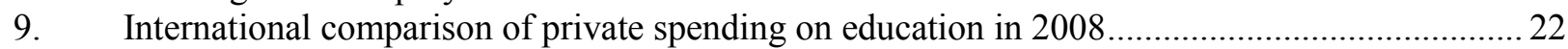

10. The percentage of students attending after-school lessons in Korea is exceptionally high...........24

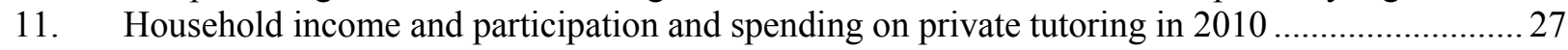

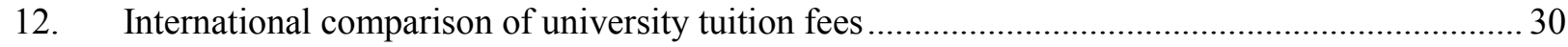

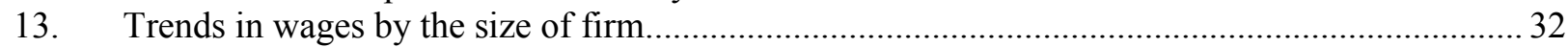

\section{Boxes}

Box 1. Why parents send their children to private, after-school lessons................................................22

Box 2. Summary of recommendations to promote social cohesion ..................................................... 33 


\title{
PROMOTING SOCIAL COHESION IN KOREA
}

\author{
By Randall S. Jones and Satoshi Urasawa ${ }^{l}$
}

1. During its high growth era, which lasted until the 1997 Asian financial crisis, Korea combined rapid growth with a relatively equal income distribution. As in most OECD countries, however, the gap between rich and poor in Korea has expanded in recent years (Figure 1), an alarming trend in a country with a tradition of egalitarianism and homogeneity. Inequality has risen to the top of the political agenda, as evidenced, for example, by the issues of half-price tuition and school lunches in Seoul and by entrenched labour market dualism. Already in 2008, a survey of 34 countries found that the share of the population that felt that the benefits and burdens of economic development have not been fairly distributed in their country was highest in Korea at $86 \%{ }^{2}$ Korea faces the challenge of returning to its pre-crisis pattern that combined strong economic growth with improving equality.

Figure 1. Income inequality and relative poverty are increasing ${ }^{1}$

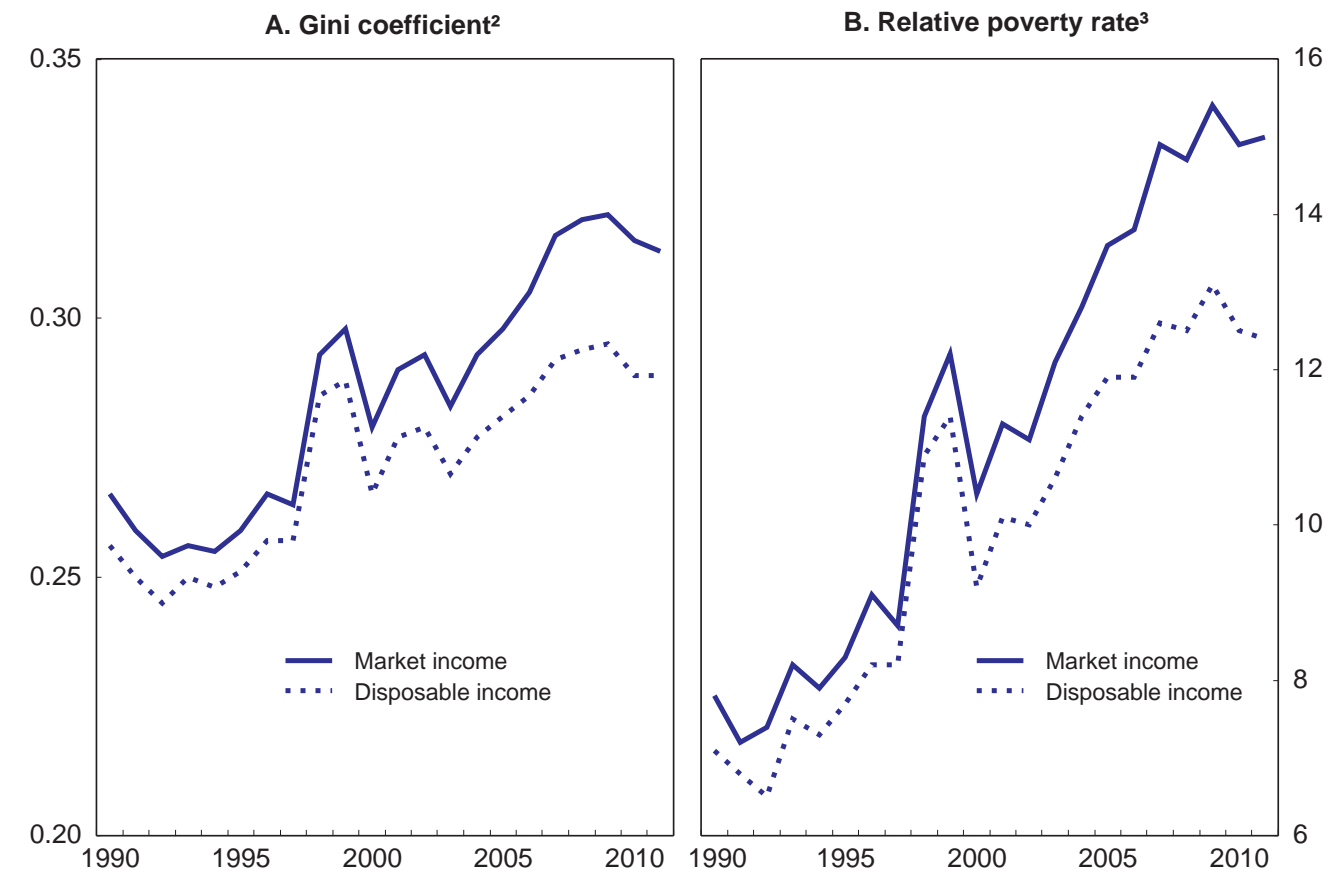

1. For urban households with at least two persons.

2. The Gini coefficient can range from 0 (perfect equality) to 1 (perfect inequality).

3. Relative poverty is defined as the share of the population that lives on less than half of the median income.

Source: Statistics Korea.

1. Randall S. Jones is head of the Japan/Korea Desk in the Economics Department of the OECD and Satoshi Urasawa is an economist on the Desk. This paper is based on material from the OECD Economic Survey of Korea published in April 2012 under the authority of the Economic and Development Review Committee (EDRC). The authors would like to thank Willem Adema, Inyup Choi, Hyoung-Woo Chung, Andrew Dean, Robert Ford, Mark Keese, Vincent Koen, Minwon Lee and Byungseo Yoo for valuable comments on earlier drafts. Special thanks go to Lutécia Daniel for technical assistance and to Nadine Dufour and Pascal Halim for technical preparation.

2. The survey was a BBC World Service poll of 34500 persons. 
2. The widening income disparity reflects a number of structural changes that would be very difficult for the government to reverse. Moreover, Korea's international competitiveness and continued output growth depend on such structural changes, making it important for the authorities to facilitate, rather than hinder, such changes. At the same time, it is clear that Korea's robust growth, at an annual rate of $4 \%$ since 2000, has not been sufficient in itself to address the problems of inequality and poverty. Korea should therefore promote social cohesion through effective and well-targeted social spending, while avoiding wasteful outlays and negative incentives. Public social spending has been increasing at a $12 \%$ annual rate, adjusted for inflation, since 1990 and population ageing alone will sustain that momentum. A government research institute estimated that public social spending under current policies would increase from less than $8 \%$ of GDP in 2011 to between 17.6 and $21.1 \%$ by 2050 , depending on assumptions about economic growth (Won et al., 2011). Given the difficulty of scaling back social spending, as seen in some European countries, Korea needs to be cautious in expanding social welfare programmes. In addition, higher social spending needs to be financed, at least in part, by higher taxes, which tend to have a negative impact on growth even when they are carefully designed to limit such effects (2012 OECD Economic Survey of Korea). After a brief review of trends in inequality and social spending, this paper discusses priorities for social spending.

3. Korea should also address the underlying causes of inequality. A recent OECD study concluded that while technological change and globalisation play at least some role in driving inequality patterns, structural policy can also have an important influence on inequality outcomes, in particular through education and labour market policies (Koske et al., 2011). After considering social spending, the following sections discuss reforms in the labour market and the education system, as well as the service sector, which would help reduce inequality. Policy recommendations are summarised in Box 2 at the end of the paper.

\section{Rising income inequality and relative poverty and the factors behind it}

4. Between 1960 and the mid-1990s, Korea achieved one of the highest growth rates in the world, while its income distribution stood out as one of the most equitable among developing countries (Sakong, 1993). Indeed, wage inequality declined during the 1980s and the first half of the 1990s (Kang and Yun, 2008). Korea's outstanding performance was cited as support for the hypothesis of a positive relationship between growth and equity (Alesina and Rodrik, 1994). However, the 1997 Asian financial crisis sparked a jump in both income inequality and relative poverty (Figure 1). Despite Korea's strong economic recovery, these two indicators continued to deteriorate steadily during the past decade. On a disposable income basis (i.e. after taxes and transfers), the Gini coefficient matched the OECD average of 0.315 in 2008. Moreover, the ratio of the top quintile to the bottom in Korea was 5.7, compared to the OECD average of 5.4 (OECD, 2011b). While there was a small improvement in 2010-11 in inequality indicators for urban households, it is too early to conclude that the deterioration in equality has been stopped.

5. Meanwhile, the relative poverty rate doubled between 1996 and 2008, based on market income. According to the OECD measure based on disposable income, the poverty rate was $15 \%$ in 2008 , the seventh highest in the OECD area (Figure 2), reflecting a high rate of $47 \%$ for the elderly. Nevertheless, $88 \%$ of the poor were in households headed by a working-age person and the rate among them is increasing rapidly (Koh, 2011). There is a growing consensus that assessments of economic growth should not focus solely on income growth, but should take into account income distribution (Stiglitz et al., 2009).

6. There has been considerable debate on the factors responsible for rising inequality, focusing on the roles of technological progress and globalisation. First, technological progress has tended to shift production technologies in favour of skilled labour. Korea, the OECD country with the largest increase in wage dispersion, also has relatively rapid technological change, as measured by $R \& D$ spending in the business sector. However, the positive association of wage dispersion and technology in the OECD area is weak (OECD, 2011b). Second, the rapid integration of trade and financial markets, particularly with 
developing countries, may have generated a relative shift in labour demand in favour of highly skilled workers. In Korea, though, the degree of wage inequality is very similar in the tradable and non-tradable industries and they have followed similar patterns in recent years (An and Bosworth, 2011). Third, changes in household structure - notably the increase in single-headed households - have increased inequality, although it was much less important than changes related to the labour market (OECD, 2011b).

7. In the case of Korea, a key factor was structural change in the economy. During the high growth period, labour shifted from low-paying jobs in agriculture to higher-paying jobs in manufacturing and services, thus reducing inequality. However, the share of employment in manufacturing has fallen from $28 \%$ in 1990 to $18 \%$ by 2007 . The shift from high-paying jobs in manufacturing to lower-paying jobs in services has increased inequality. A second major factor, discussed below, is labour market dualism, which results in large wage gaps between regular and non-regular workers.

\section{Figure 2. International comparison of relative poverty rates ${ }^{1}$}

\section{In 2008 or latest year available}

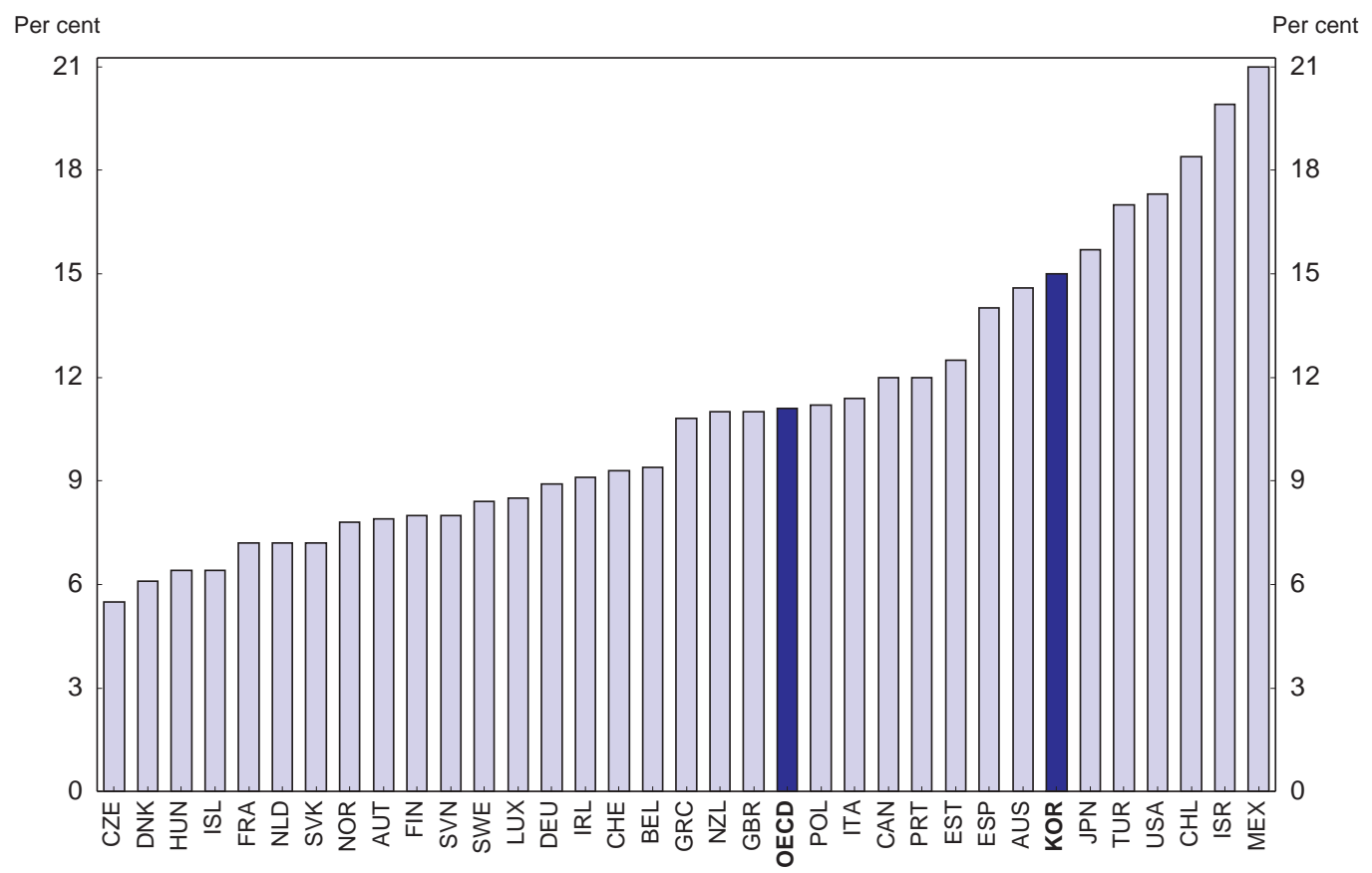

1. The poverty rate is defined as the share of individuals with equivalised disposable income less than $50 \%$ of the median for the entire population. The income concept used is that of household disposable income adjusted for household size. Data for Chile are for 2009.

Source: OECD (2011b), Divided We Stand: Why Inequality Keeps Rising.

\section{Social spending is low but increasing rapidly}

8. The development of social spending in Korea, which was still one of the poorest countries in the world only 50 years ago, is relatively recent. Landmark events include the introduction of a public pension system in 1988, universal health insurance in 1989 and unemployment insurance in 1995. The rapid rise in public social spending boosted its share of GDP from 2.8\% in 1990 to $7.6 \%$ in 2007 (Figure 3). 
Figure 3. International comparison of public social spending

Per cent of GDP

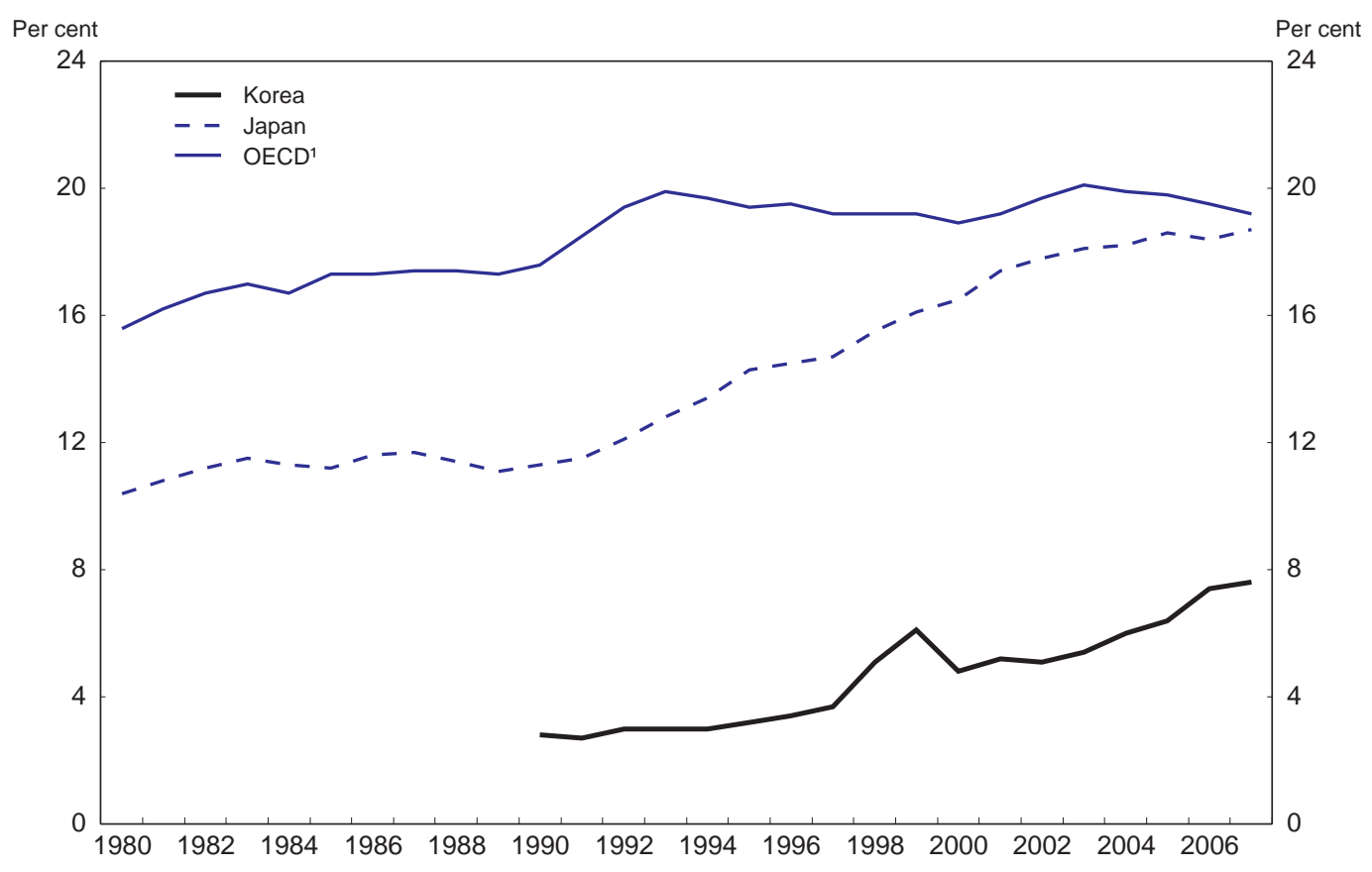

1. Data are available for 34 OECD countries from 2000. Data prior to 2000 have been interpolated backwards from an unweighted OECD average of 23 countries.

Source: OECD Social Expenditure Database.

9. However, the upward trend in social welfare spending has been inadequate to stop the deterioration in income distribution, reflecting several factors. Most importantly, gross public social spending in Korea is the second lowest in the OECD area and well below the OECD average of 19.2\%. The gap on a net basis is less, reflecting Korea's relatively low tax burden, which means less of the benefits are "clawed back". In addition, private social spending, both mandated and voluntary, is slightly above average in Korea. Nevertheless, total net social spending (public and private) amounted to $10.4 \%$ of GDP, the second lowest in the OECD area and well below the OECD average of $19.6 \%$. In the wake of the 2008 global financial crisis, gross public social spending in Korea is estimated to have increased by 1.4 percentage point to $9.0 \%$ of GDP in 2010 , compared to a 3.0 percentage-point rise in the OECD average to $22.2 \%$ (Adema et al., 2011).

10. Public social spending in Korea was lower than the OECD average in each of the major areas (Figure 4):

- Pensions: Korea's spending of $1.7 \%$ of GDP was only a quarter of the OECD average, reflecting the relatively recent introduction of the National Pension Scheme (NPS) and its young population.

- Income support to the working-age population: Korea's outlays of $0.8 \%$ are far below the OECD average of $3.9 \%$, due in part to the low number of persons receiving unemployment benefits. Moreover, support for families, such as child benefits and childcare support, amounted to only $0.5 \%$ of GDP, the lowest in the OECD and well below the OECD average of $2.2 \%$ (OECD, 2011a). 
- Health care: Korea's low share of $3.5 \%$ reflects its relatively young population, the limited coverage of the National Health Insurance and high co-payment rates.

As a result, government transfers accounted for only $2.7 \%$ of disposable income in Korea, the second lowest in the OECD area and well below the average of 12.3\%, after accounting for taxes (OECD, 2011b).

Figure 4. The composition of public social spending in Korea compared to the OECD average

As a per cent of GDP in 2007

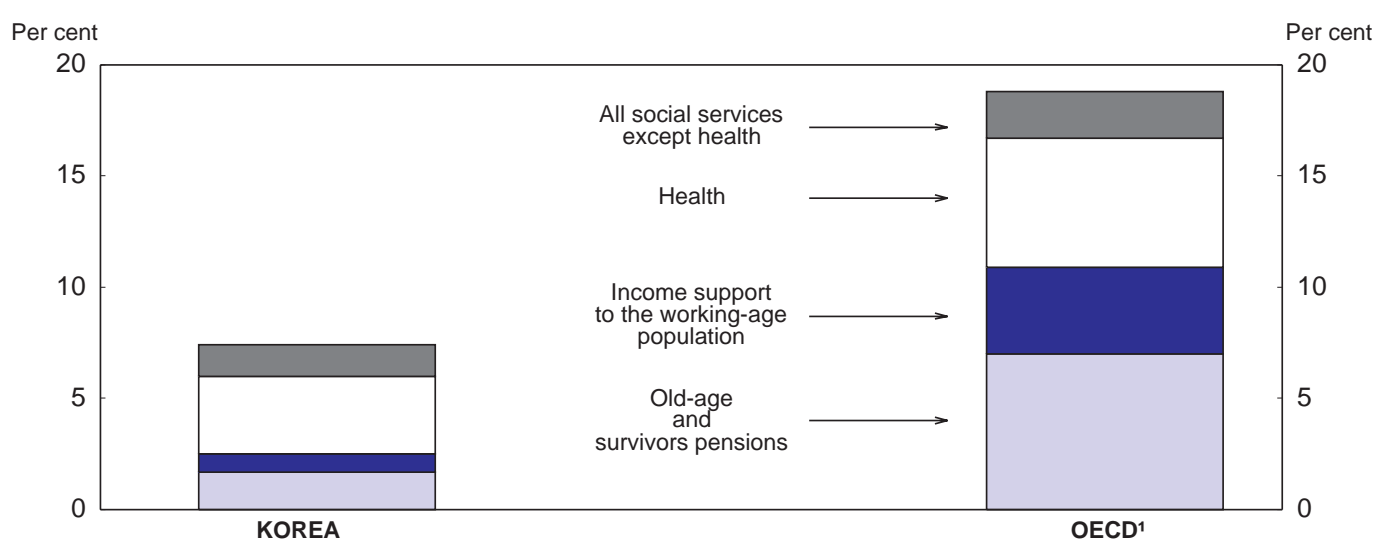

1 Weighted average of the 34 OECD countries.

Source: OECD Social Expenditure Database.

11. Besides its low level, social spending is not well targeted, as only a quarter of total cash benefits from the government go to the poorest $20 \%$ of the population. The problem of poor targeting is partly due to blind spots in coverage, particularly among the self-employed and non-regular workers. Meanwhile, the tax burden in Korea is low - 25\% of GDP compared to an OECD average of 33\% in 2010 - and has little impact on income distribution because Korea is one of only a few countries that combines a relatively low tax burden with very little progressivity (Joumard et al., 2012). Consequently, Korea's tax/benefit system is the least effective among OECD countries in fostering equality. Indeed, it reduced the relative poverty rate in 2008 by only 2.5 percentage points relative to market incomes, the lowest in the OECD area. In OECD countries, the tax/benefit system reduces relative poverty by an average of 15 percentage points.

\section{Increasing social spending to promote social cohesion}

12. Given its limited impact and gaps in coverage, reforms are needed to improve social welfare. The government should move cautiously and incrementally in developing social welfare programmes that are carefully designed to achieve their intended objectives, while avoiding wasteful spending and negative externalities. Public social spending increased at an 11\% annual rate in real terms between 1990 and 2007, the fastest in the OECD area. Under current policies, however, population ageing alone is projected to boost public social spending from $7 \frac{1}{2}$ per cent of GDP at present to around $20 \%$ by 2050 (Won et al., 2011). Consequently, social spending increases should be targeted at those most in need rather than provided universally. The main priorities are the Basic Livelihood Security Programme, the earned income tax credit, the Basic Old-Age Pension and the ceiling on co-payments for health care. In addition, it is important to upgrade the collection of premium payments. 


\section{The Basic Livelihood Security Programme (BLSP)}

13. The BLSP, Korea's major welfare programme, provides cash and a package of in-kind benefits, including housing, medical and educational benefits, to those living under the absolute poverty line. Although BLSP benefits have increased at a double-digit rate, they amounted to only $0.9 \%$ of GDP in 2009 . Benefits are provided to only $3 \%$ of the population, half of those below the absolute poverty line and far below the $15 \%$ living in relative poverty. The limited coverage is due to strict eligibility requirements that include income, assets and the possibility of assistance from family members. The BLSP is administered by local governments, which must cover 10 to $60 \%$ of the costs, a policy aimed at controlling outlays. Facing this considerable financial burden, local authorities limit outlays for the poor. Consequently, some eligible low-income households do not receive assistance because of a lack of funds.

14. To increase the effectiveness of the BLSP, the eligibility conditions should be relaxed so as to cover all of those living below the absolute poverty line. In addition, benefits should be a right for all those who are eligible rather than dependent on local government finances. The fact that BLSP recipients receive all or none of the in-kind benefits creates strong incentives to enter the system and equally strong disincentives to leave. To improve incentives, in-kind benefits should be provided and withdrawn separately based on individual needs.

15. Beneficiaries who are able to work are required in principle to participate in training programmes run by central and local governments. In practice, $87 \%$ of able-bodied recipients were granted waivers for various reasons in 2009, suggesting a need to strengthen the training requirements. For those who do participate, the results are poor. Only $6 \%$ of those in the local government's Self-Reliance Programme were able to escape poverty (Koh, 2011). Training programmes should be consolidated to improve their effectiveness. In general, activation policies have played a small role in Korea, reflecting the low level of spending on active labour market policies at only $0.1 \%$ of GDP, well below the OECD average of $0.5 \%$.

\section{The earned income tax credit}

16. The earned income tax credit (EITC) used in a number of OECD countries is another important tool for reducing poverty. The EITC lowers taxes or provides a refund when the deduction is larger than the tax amount, thereby raising take-home pay at the low end of the income distribution. Korea introduced this in-work tax credit in 2008, targeting the 7.4 million daily and temporary workers. Previously, benefits for people who were capable of working were extremely limited, aside from the BLSP. In-work benefits have been found to raise employment rates among the targeted group, with very low efficiency costs (Hwang, 2011). The impact of an EITC in increasing total labour supply and decreasing unemployment is greater in countries with a wide earnings distribution, low tax rates on labour, low benefits for the nonemployed and a low minimum wage (Bassanini et al., 1999). As each of these conditions holds in Korea, an EITC is likely to be particularly effective and should thus be a major tool to reduce inequality and poverty. Another study found that an EITC is more effective than a minimum wage in reducing poverty and encourages employment in contrast to minimum wages (Pearson and Scarpetta, 2000).

17. Korea's EITC is at a very early stage of development. It offers a maximum of 1.2 million won (about $\$ 1050$ ) per year to those who meet strict income and property requirements, ${ }^{3}$ are employed and have at least one child under 18. Persons who received benefits from the BLSP for three months or more are excluded from the EITC. The government estimated that 0.6 million households $(3.6 \%$ of the total) received the EITC in 2009 , with total payments of 454 billion won ( $0.04 \%$ of GDP). The average payment

3. Their annual household gross income must be less than 17 million won (about $\$ 15000$ ) and assets, including real estate, cannot exceed 100 million won, meaning that EITC recipients cannot own a home. 
is thus around $\$ 680$ per household. The EITC has a steep phase-out once workers reach an annual salary of 12 million won (one-third of the average wage in 2011) and, by 17 million won, is entirely phased out.

18. To have a significant effect on income distribution, the number of recipients and the amount of benefits provided by the EITC must be expanded. Given that the average wage of the 5.8 million nonregular workers is around 16 million won per year, there would appear to be a large pool of potential recipients. The EITC was extended in 2012 to childless households and some self-employed workers, while the income ceiling on eligibility has been increased, nearly doubling the number of recipients since 2009. The ceiling on assets could be relaxed to allow homeowners to participate. A slower phase-out of the EITC would avoid negatively affecting work incentives. Finally, the EITC would be more successful if accompanied by effective activation measures, such as training, to help the unemployed find jobs that would allow them to participate in the EITC. In the long run, the goal should be to extend the EITC to the low-income among the 7 million self-employed once there is adequate transparency about their income. The self-employed, who account for about $30 \%$ of the labour force, the third-highest share in the OECD, include a large share of low-income workers.

\section{The Basic Old-Age Pension}

19. As noted above, relative poverty is much higher among the elderly. The rate for those aged 66 to 75 in Korea was nearly three times higher than the $15 \%$ rate for the entire population, in contrast to the OECD area, where it equals the overall average (Figure 5). Moreover, 37.5\% of the elderly were in absolute poverty with an income below the minimum cost of living (Bae, 2011). The high rate of poverty is explained in part by the fact that the NPS was introduced relatively recently. Consequently, only one-fifth of those over 65 receive benefits, which tend to be rather small, given the short contribution period. In addition, many poor elderly are not eligible for the BLSP on the grounds that they have working-age children, although many of those children cannot or will not support their parents.

20. The Basic Old-Age Pension System, introduced in 2008, provides assistance to elderly people who meet the income and asset criteria. At present, around $70 \%$ of the elderly receive the benefit, which is set at only $5 \%$ of the average wage. As a result, the benefit spreads out resources very thinly over a large segment of the older population while doing little to reduce poverty among the elderly. A larger benefit that is more targeted at low-income elderly would be more effective. However, if it is politically impossible to withdraw the benefit from the relatively affluent elderly, the government should at least freeze their benefits, while allowing them to grow for the relatively poor.

\section{National Health Insurance (NHI)}

21. The NHI aims at universal coverage, with $63 \%$ of the population insured as employees and $37 \%$ as self-employed. Among the latter, 2 million persons - a quarter of households - were at least three months behind in their contributions in 2008 (Kim et al., 2011). After six months, patients are denied insurance coverage. For the 3\% of the population receiving benefits from the BLSP, their insurance is covered by Medical Aid. Ensuring universal coverage may require extending Medical Aid to households that do not qualify for the BLSP.

22. Out-of-pocket payments - co-payments and the cost of non-covered services - by patients amounted to $4.6 \%$ of household final consumption in 2007, the third highest in the OECD area. The high out-of-pocket payments are inequitable and regressive because they do not depend on the income of patients, resulting in inequality in the economic burden of illness. In addition, they also increase poverty. The proportion of households below the national poverty line, defined as the minimum living expense, rises from $10.8 \%$ to $12.5 \%$ if health spending is included (Kwon, 2009). Out-of-pocket payments thus 
reduce both necessary and unnecessary health care. In addition to penalising low-income households, outof-pocket payments create a substantial burden on those with chronic health problems.

Figure 5. The rate of relative poverty by age group ${ }^{1}$

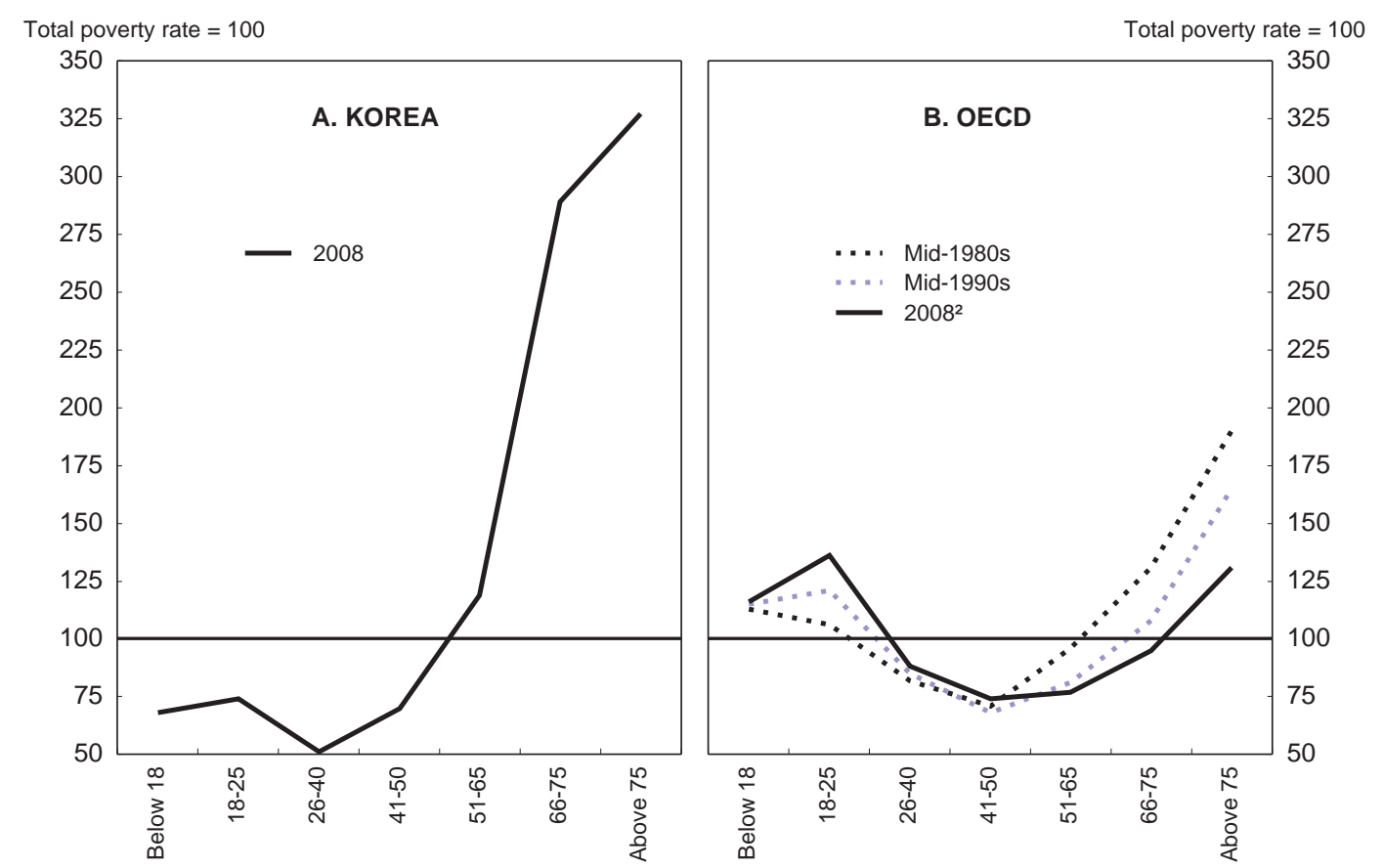

1. The figure shows the poverty rate for each age group using an index, with the rate for the entire population set at 100 . The poverty threshold is set at $50 \%$ of median income of the entire population. The OECD average includes 20 member countries.

2. Data refer to the most recent year in the late-2000s (2008 for most countries).

Source: OECD Database on Income Distribution and Poverty (www.oecd.org/els/social/inequality).

23. Ceilings on co-payments introduced in 2004 limited them to 3 million won (around \$2 665) every six months. Consequently, a patient might pay up to 6 million won per year, or $51 \%$ of average per capita household disposable income. The ceiling system was revised in 2009 to take account of the insured's ability to pay, as measured by the amount of social insurance payments. However, such payments may not be the best measure of ability to pay, given the underpayment by the self-employed. For the lower half of households, co-payments are limited to 2 million won each year, 3 million won for the next $30 \%$ and 4 million won for the top 20\%. However, for a person earning half of the average disposable income per capita, co-payments could still be as high as one-third of their income. In sum, the NHI states that "the current level of protection still falls short of being adequate in terms of risk protection" (NHIC, 2009), making it important to further reduce ceilings.

\section{Improving participation in social insurance programmes}

24. Weak coverage of the NPS and the EIS is a problem for non-regular workers. For NHI, those not covered through their workplace are nevertheless insured. Overall, only around $40 \%$ of non-regular workers are covered by workplace-based social insurance systems. Coverage is particularly low at small firms, which tend to have a higher proportion of non-regular workers. Indeed, more than half of employees at firms with less than ten workers are not covered by any of the three major social security systems, compared to only $4.6 \%$ at firms with more than 100 workers (Table 1 ). The generally precarious financial health of SMEs is one factor that discourages the payment of premiums on behalf of their employees. 
ECO/WKP(2012)40

Table 1. Participation rates of employees in the NPS, NHI and EIS ${ }^{1}$

In per cent

\begin{tabular}{|c|c|c|c|c|}
\hline \multirow{2}{*}{ Share of employees participating in: } & \multirow[b]{2}{*}{ Total } & \multicolumn{3}{|c|}{ By firm size (number of workers) } \\
\hline & & $1-9$ & $10-99$ & More than 100 \\
\hline All three programmes & 64.5 & 39.2 & 73.5 & 92.1 \\
\hline One or two programmes & 5.4 & 5.3 & 6.2 & 3.3 \\
\hline None & 30.1 & 55.5 & 20.3 & 4.6 \\
\hline Total & 100.0 & 100.0 & 100.0 & 100.0 \\
\hline
\end{tabular}

1. The three major social security programmes are the National Pension Scheme, National Health Insurance and the Employment Insurance System. Employees not covered through their workplace are still insured by the NHI.

Source: Koh (2011).

25. The inadequate coverage of the NPS needs to be addressed. In $2010,30 \%$ of the working-age population did not contribute to public pension programmes, even though participation is mandatory. The share of workers not participating is three times higher among high school graduates than tertiary graduates, even though the NPS has a very strong redistributive element (Chang, 2011). Some of the participants will not be able to draw pension benefits after retirement because they have not completed the minimum contribution period (ten years in case of the NPS). Even if they qualify, the amount of pension benefits may be too small to prevent poverty. For a participant with 40 years of contributions, benefits will amount to only $40 \%$ of their average lifetime earnings, well below the OECD average of $58 \%$ (OECD, 2011d). Moreover, many under-report income, further reducing their eventual benefits.

26. The government announced a plan in 2011 to subsidise SME contributions to social insurance systems (see below), which should help boost coverage. It is essential, though, to improve compliance with social insurance systems to expand the coverage of the social safety net. Each insurance system has evolved independently, with a lack of co-ordination with the other systems, especially in terms of collecting contributions. Beginning in 2011, the collection of social insurance was combined under the NHI. Transparency about income and compliance could be further improved by having the National Tax Service collect social insurance contributions, as it would allow the authorities to compare firms' wage costs as reported on their tax forms with their social insurance contributions. However, the impact on compliance would be limited by the fact that $40 \%$ of employees are not subject to income tax. The fundamental problem is labour market dualism, i.e. the large share of non-regular workers who slip through the social safety net, which is discussed in the following section.

\section{Labour market reforms to promote social cohesion by breaking down dualism}

27. Korea is one of five OECD countries identified as having a high degree of inequality originating in the labour market (Koske et al., 2011). A key factor is the high share of non-regular workers - which includes fixed-term, part-time and atypical workers (such as those from temporary worker agencies). Regular workers are characterised by high wages, employment inflexibility, high employment protection and broad coverage by the social safety net and active labour market policies (Table 2). In contrast, nonregular workers face low wages, unstable employment, low employment protection and weak coverage by the social safety net and active labour market policies. The share of temporary workers, who account for more than one-third of non-regular workers in Korea, was the fourth highest in the OECD area in 2010 (Figure 6). 
Figure 6. International comparison of temporary employment

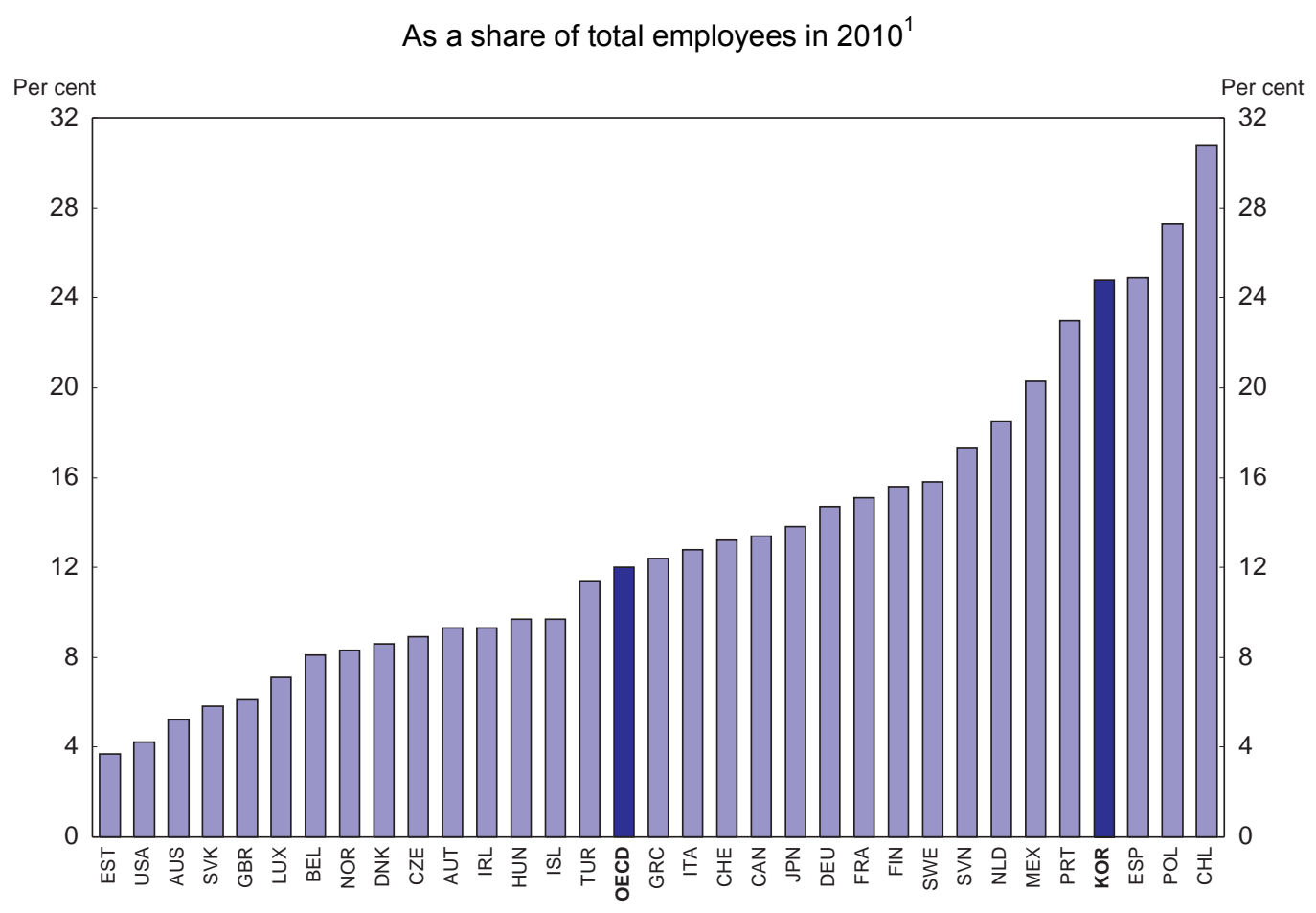

1 Temporary employees are defined as wage and salary workers whose job has a pre-determined termination date. For Korea, it includes only workers with a fixed-term contract, temporary agency workers and on-call workers (excluding double-counting).

Source: OECD Employment Outlook Database.

\section{Factors explaining the high level of labour market dualism}

28. Korea's rapid integration in a globalised economy, particularly following the 1997 Asian crisis, intensified competition, prompting firms to reduce fixed costs, including labour, and pursue employment flexibility by hiring non-regular workers (Koh et al., 2010). Indeed, non-regular workers were paid only $53 \%$ as much as regular workers per hour in 2010. According to a government survey, $32.1 \%$ of firms cited reducing costs as the most important reason for hiring non-regular workers (Table 3 ). Their lower wages are explained in part by productivity differences. However, the gap remains significant at $13 \%$, according to the government, after adjusting for workers' tenure, gender, age and educational attainment, suggesting that discrimination plays a role. Another study estimated the gap at 7\% (KDI, 2009), while the Korea Employers Federation estimated the productivity gap at 22\% below regular workers, about half the gap in wages (KEF, 2006). If the wage gap were entirely explained by productivity differences, firms would have less reason to hire non-regular workers to reduce labour costs. Non-regular workers are primarily in fixedterm positions and work as substitutes for regular workers (Kim, 2010). In addition to lower hourly wages, the labour costs for non-regular workers are reduced another $6 \frac{1}{2}$ per cent by their relatively low participation in social insurance systems, which reduces firms' contributions. On top of this, non-regular workers receive fewer welfare benefits from firms. The savings on welfare costs adds up to $10 \%$.

29. The second major reason for hiring non-regular workers is to increase employment flexibility (Table 3). The reforms adopted in the wake of the 1997 Asian financial crisis strengthened competition by reducing import barriers, liberalising restrictions on foreign direct investment inflows and upgrading competition policy (2000 OECD Economic Survey of Korea). Such reforms increased Korea's integration in the world economy, with imports' share of GDP doubling from a quarter in 1993 to one-half by 2008. 
These factors made employment flexibility a priority for firms, especially large ones, given the difficulty and cost of laying off regular workers, who receive relatively high employment protection as a result of government policies, business practices, social customs and labour unions (Koh et al., 2010). According to the Ministry of Employment and Labour, "Regular workers enjoy a high level of legal protection in Korea and managements' employment adjustment decision often faces strong opposition, which is still prevalent in the Korean labour market". The importance of non-regular workers as a buffer against cyclical shocks has become increasingly evident since the 1997 crisis, as their share has become more closely correlated with economic cycles.

Table 2. Flexibility and security in the Korean labour market

\begin{tabular}{|c|c|c|c|c|c|}
\hline \multirow[b]{2}{*}{ Types of workers } & \multicolumn{2}{|c|}{ Flexibility } & \multicolumn{3}{|c|}{ Security } \\
\hline & $\begin{array}{l}\text { Numerical }^{1} \\
\text { flexibility }\end{array}$ & $\begin{array}{c}\text { Functional }^{2} \\
\text { flexibility }\end{array}$ & $\begin{array}{c}\text { Employment } \\
\text { protection }\end{array}$ & Social safety net & $\begin{array}{c}\text { Active labour } \\
\text { market policies }\end{array}$ \\
\hline $\begin{array}{l}\text { Regular workers in the } \\
\text { manufacturing sector } \\
\text { and/or in large } \\
\text { corporations }\end{array}$ & $\begin{array}{l}\text { Very low } \\
\text { flexibility }\end{array}$ & $\begin{array}{l}\text { Very low } \\
\text { flexibility }\end{array}$ & High & $\begin{array}{l}\text { Included in } \\
\text { coverage, albeit } \\
\text { ineffective }\end{array}$ & $\begin{array}{l}\text { Included in } \\
\text { coverage, albeit } \\
\text { inefficient }\end{array}$ \\
\hline $\begin{array}{l}\text { Non-regular workers in } \\
\text { the service sector and/or } \\
\text { SMEs }\end{array}$ & $\begin{array}{l}\text { High labour } \\
\text { mobility, low job } \\
\text { security }\end{array}$ & No flexibility & Very low & $\begin{array}{l}\text { Mostly excluded } \\
\text { from coverage }\end{array}$ & $\begin{array}{l}\text { Mostly excluded } \\
\text { from coverage }\end{array}$ \\
\hline
\end{tabular}

1. The ability of firms to adjust its labour inputs to accommodate changes in demand.

2. The ability of firms to deploy workers between tasks as demand for different types of labour changes.

Source: Koh et al. (2010).

Table 3. Reasons given by firms for hiring non-regular workers

Percentages based on a government survey of firms

\begin{tabular}{lcccccc}
\hline & $\begin{array}{c}\text { Reduce } \\
\text { labour costs }\end{array}$ & $\begin{array}{c}\text { Increase } \\
\text { employment } \\
\text { flexibility }\end{array}$ & $\begin{array}{c}\text { Perform } \\
\text { peripheral } \\
\text { tasks }\end{array}$ & $\begin{array}{c}\text { Perform } \\
\text { short-term } \\
\text { tasks }\end{array}$ & $\begin{array}{c}\text { Other } \\
\text { reasons }\end{array}$ & Total \\
\hline All industries & $\mathbf{3 2 . 1}$ & $\mathbf{3 0 . 3}$ & $\mathbf{1 8 . 5}$ & $\mathbf{1 3 . 9}$ & $\mathbf{5 . 2}$ & $\mathbf{1 0 0 . 0}$ \\
$\quad$ Manufacturing & 28.7 & 34.5 & 17.9 & 14.7 & 4.1 & 100.0 \\
$\quad \begin{array}{l}\text { Non-manufacturing } \\
\text { By firm size }\end{array}$ & 35.4 & 26.1 & 19.1 & 13.2 & 6.2 & 100.0 \\
Less than 30 &. & & & & & \\
30-99 workers & 35.5 & 28.9 & 15.8 & 13.2 & 6.6 & 100.0 \\
100-299 workers & 28.5 & 27.6 & 18.7 & 18.2 & 7.0 & 100.0 \\
300-499 workers & 37.7 & 26.2 & 15.5 & 14.3 & 6.3 & 100.0 \\
More than 500 & 34.3 & 29.4 & 19.6 & 12.7. & 3.9 & 100.0 \\
\hline Source: OECD (2007). & 28.1 & 49.9 & 22.9 & 9.6 & 1.6 & 100.0 \\
\hline
\end{tabular}

30. A 2011 government survey found that slightly less than half of non-regular workers voluntarily accepted non-regular status (Table 4). Consequently, $52 \%$ of the 5.8 million non-regular workers - about 3 million employees - are involuntarily employed as non-regular workers, a group that is 3.5 times larger than the 0.85 million unemployed in 2011. Atypical workers, such as dispatched workers, are the least likely to voluntarily accept non-regular employment. The high share of non-regular workers is thus driven primarily by firms' need for employment flexibility and lower wage costs, rather than by workers'

4. Response provided to an OECD questionnaire. 
preferences. The workers who involuntarily work in non-regular employment accept it primarily to obtain immediate income. As a group, non-regular workers tend to be older, less educated, employed in SMEs, have shorter tenure and work in the service sector. In addition, women are over-represented; $42 \%$ of female employees are in non-regular employment compared to $28 \%$ of males.

Table 4. Reasons given by non-regular workers for accepting non-regular employment

\begin{tabular}{l|c|ccc}
\hline & Total & $\begin{array}{c}\text { Temporary } \\
\text { workers }\end{array}$ & $\begin{array}{c}\text { Part-time } \\
\text { workers }\end{array}$ & $\begin{array}{c}\text { Atypical } \\
\text { workers }\end{array}$ \\
\hline Voluntary non-regular workers & $\mathbf{4 7 . 6}$ & $\mathbf{5 5 . 1}$ & $\mathbf{4 4 . 7}$ & $\mathbf{3 5 . 4}$ \\
\hline Satisfied with working condition & 44.4 & 49.5 & 35.3 & 40.4 \\
To obtain job security $^{\text {To balance work with other activities }}{ }^{1}$ & 23.2 & 30.7 & 3.5 & 17.2 \\
To have more flexibility in work hours $^{2}$ & 19.0 & 14.1 & 43.5 & 14.1 \\
\hline Involuntary non-regular workers $^{2}$ & 13.4 & 5.6 & 17.7 & 28.4 \\
\hline To obtain immediate income $_{\text {Cannot find a desirable job }}$ & $\mathbf{5 2 . 4}$ & $\mathbf{4 4 . 9}$ & $\mathbf{5 5 . 3}$ & $\mathbf{6 4 . 6}$ \\
To balance work with other activities $^{1}$ & 13.0 & 74.6 & 68.3 & 83.5 \\
\hline
\end{tabular}

1. Includes balancing work with family responsibilities and educational and vocational training, as well as to accumulate job experience.

2. This category includes obtaining performance-based pay.

Source: Statistics Korea.

31. The negative consequences of dualism are exacerbated by the lack of mobility between nonregular and regular employment. According to one government report, "The severity of the non-regular work issue in Korea is derived from the fact that non-regular workers find it very difficult to escape from the trap of non-regular work" (Chung, 2008). In other words, non-regular employment is unlikely to be a stepping stone into regular jobs (KDI, 2009), in contrast to many other OECD countries, where a large share of temporary workers moves into permanent employment (OECD, 2006). The probability of making the transition to regular status tends to be higher for younger male workers in large manufacturing firms with longer tenures (Kim, 2009).

\section{The impact of the 2007 labour law reform}

32. After five years of discussion with the social partners, the government reformed the labour law in 2007 to prohibit unreasonable discrimination against fixed-term, part-time and temporary agency workers. ${ }^{5}$ Between July 2007 and February 2012, 2443 cases affecting 5262 workers have been filed with the Labour Relations Commission. Some workers facing discrimination have reportedly chosen not to bring their cases to the Commission for fear of reprisals. ${ }^{6}$ Nevertheless, a considerable number of firms have endeavoured to reduce discrimination against non-regular workers since the 2007 reform. This may have contributed to the slight narrowing in the wages of non-regular workers from $85 \%$ of regular workers in 2007 to $87 \%$ (after adjusting for differences in individual characteristics, such as gender, education, tenure, occupation and age) in 2010.

5. The reform, which amended the Fixed-Term Employment Act and the Act on the Protection, etc. of Temporary Agency Workers, took effect in July 2007.

6. To address this problem, the Fixed-Term Employment Act and the Act on the Protection, etc. of Temporary Agency Workers have been amended. Under the revised law, which is to take effect in August 2012, labour inspectors have to encourage employers to correct any discrimination that may be found, even if there is no request from the workers. If the employers fail to remedy the situation, the case should be reported to the Labour Relations Commission. 
33. In addition, the 2007 reform limited the length of employment for non-regular workers to a maximum of two years, with some exceptions, to avoid their "excessive use". ${ }^{7}$ According to a government survey of fixed-term workers whose contracts expired after working more than 18 months:

- $22 \%$ were converted to non-fixed-term contract workers. Most firms reportedly did not change the salaries of the converted workers to the level of other regular workers, thus creating a third category in the workplace - regular workers without the wages and benefits of regular workers (Kwon, 2010). According to the Korea Federation of Trade Unions, the non-regular workers converted to regular status are paid two-thirds as much as other regular workers.

- $32 \%$ were considered non-fixed-contract workers, regardless of whether their employers took action to change their contract.

- $45 \%$ did not have their contracts renewed. As expected, the limit on temporary workers led to large-scale termination of contracts, as many firms opted to end the contracts of those nearing the two-year limit rather than elevate them to regular status (Korea Labor Review, NovemberDecember 2011).

34. The $6 \%$ increase in the number of non-regular workers between 2006 and 2011 indicates that the 2007 reform has not reduced the number of non-regular workers, even though their share of employment has fallen, and the labour market remains severely segmented. At the same time, there has been a diversification in the types of non-regular workers, away from fixed-term contracts and towards part-time and atypical work. ${ }^{8}$ In sum, the 2007 reform has helped the fixed-term workers who are now considered to be non-fixed-term workers. The key question is the outcomes for the $45 \%$ whose contracts are terminated before the two-year limit is reached. If they are not hired by another firm or find self-employment, the 2007 reform would boost unemployment while lowering the employment rate. Even if total employment is maintained, the 2007 reform substantially increases job instability for the largest group of non-regular workers. In other words, the increased transition to regular status for some fixed-term workers comes at the cost of greater job instability for a larger share of fixed-term workers.

\section{Problems associated with the high share of non-regular workers}

35. Increasing the share of regular workers would have the advantages of promoting job stability and firm-provided training, while enhancing the development of social insurance systems. On the other hand, the persistently high share of non-regular workers benefits firms, in terms of labour costs and flexibility, and accommodates workers who prefer more flexible work patterns. However, dualism has a number of negative effects, which are discussed in this section.

36. First, it increases wage disparity and relative poverty. As noted above, non-regular workers are paid $42.7 \%$ less than regular workers, due in part to discrimination. The fact that most non-regular workers do almost the same tasks as regular workers and work the same hours makes the wage differential problematic (Kim, 2010). Indeed, more than a quarter of full-time workers in Korea earn less than twothirds of the median wage, the highest share in the OECD area, thus fuelling inequality. The low wages of non-regular workers has been a key factor in the rise in the Gini coefficient and relative poverty.

7. The government has 341 thousand non-regular workers, of which about half are fixed-term workers. It announced in December 2011 that it intends, in principle, to give indefinite contracts to those who are engaged in permanent and full-time work. The number of eligible employees is estimated at 97 thousand (Korea International Labour Foundation, 2011).

8. The falling share of fixed-term workers and the rising share of other categories has slightly increased the average tenure of non-regular workers from 2.1 years in 2006 to 2.3 years in 2011. 
According to a recent study (Lee, 2011), 20\% of non-regular workers are in relative poverty. In addition, a 2009 study found that the rate of poverty among the working-age population was only $1.5 \%$ for regular workers, but as high for $13.5 \%$ for temporary employees and $26.3 \%$ for day labourers (Figure 7 ).

Figure 7. Poverty rate among working-age population in 2006 by employment status ${ }^{1}$

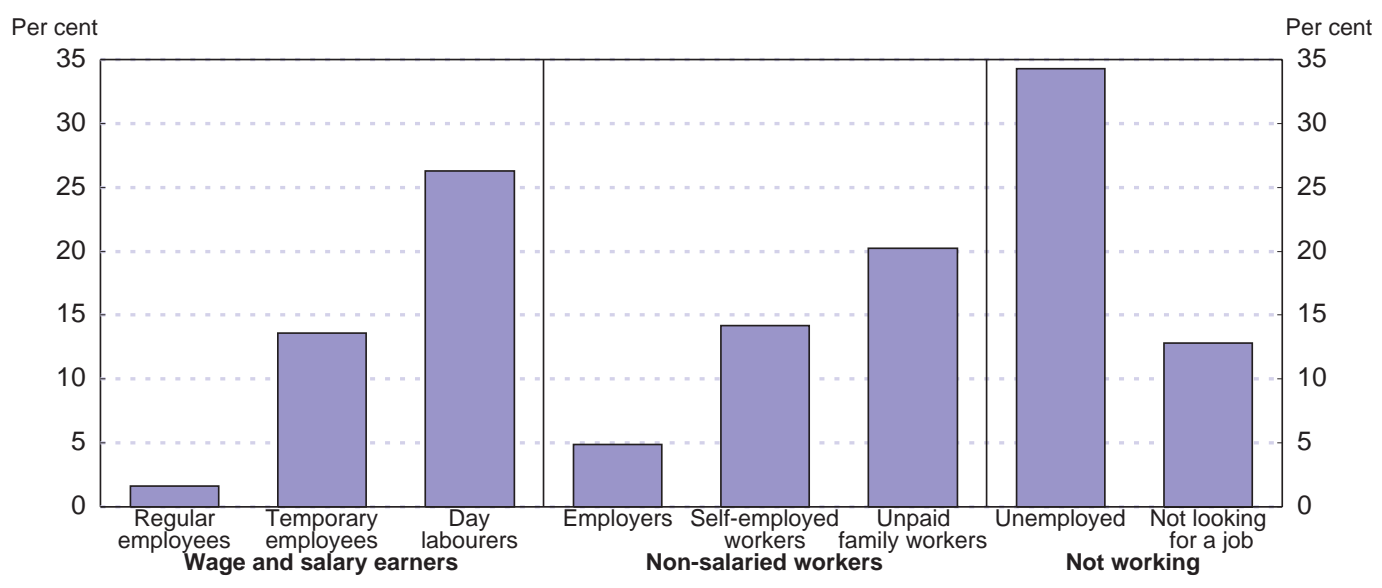

1. The poverty rate of the entire sample was $11.1 \%$.

Source: No et al., (2009).

37. Second, equity concerns are exacerbated by the low share of non-regular workers covered by social insurance, as noted above. The legal framework requires nearly all workers to be covered by the social insurance system, including the Employment Insurance System (EIS). ${ }^{9}$ In practice, however, there is a large gap between the statutory coverage and actual coverage, with many non-regular workers excluded (Korea Labor Review, March-April 2009). Indeed, in 2011, only 38\% and 44\% of non-regular workers were enrolled in the NPS and NHI, respectively, at their workplace, while $42 \%$ were enrolled in the EIS. Gaps in coverage thus reflect weak compliance, particularly among small firms. While the share of unemployed receiving benefits has risen from $7 \%$ in 2000 to over 30\% in 2007 (Figure 8), the limited coverage of the EIS undermines its effectiveness, including in its other activities, such as paying for training and maternity leave. Weak coverage helps to explain why public social spending was only $7.6 \%$ of GDP in 2007.

38. Entrenched dualism creates conflicts between regular workers (the insiders) and non-regular workers (the outsiders). Many unions do not allow non-regular workers to join and few seek to represent them, given that non-regular workers are substitutes for regular workers (Kim, 2010) and thus pose a risk to the job security of union members. Enterprise-based collective bargaining agreements thus, in general, do not cover non-regular workers. Companies with unions have higher shares of non-regular workers, suggesting that they are particularly valued for employment flexibility. Including non-regular workers in unions may help reduce inequality between regular and non-regular workers (Choi et al., 2012).

9. The EIS in principle now covers all wage and salary earners in all establishments, except: $i$ ) part-time workers working less than 60 hours a month (or 15 hours a week); ii) government officials and employees subject to the Private School Teachers' Pension Act; and iii) workers over age 65. 
Figure 8. Coverage of unemployment insurance

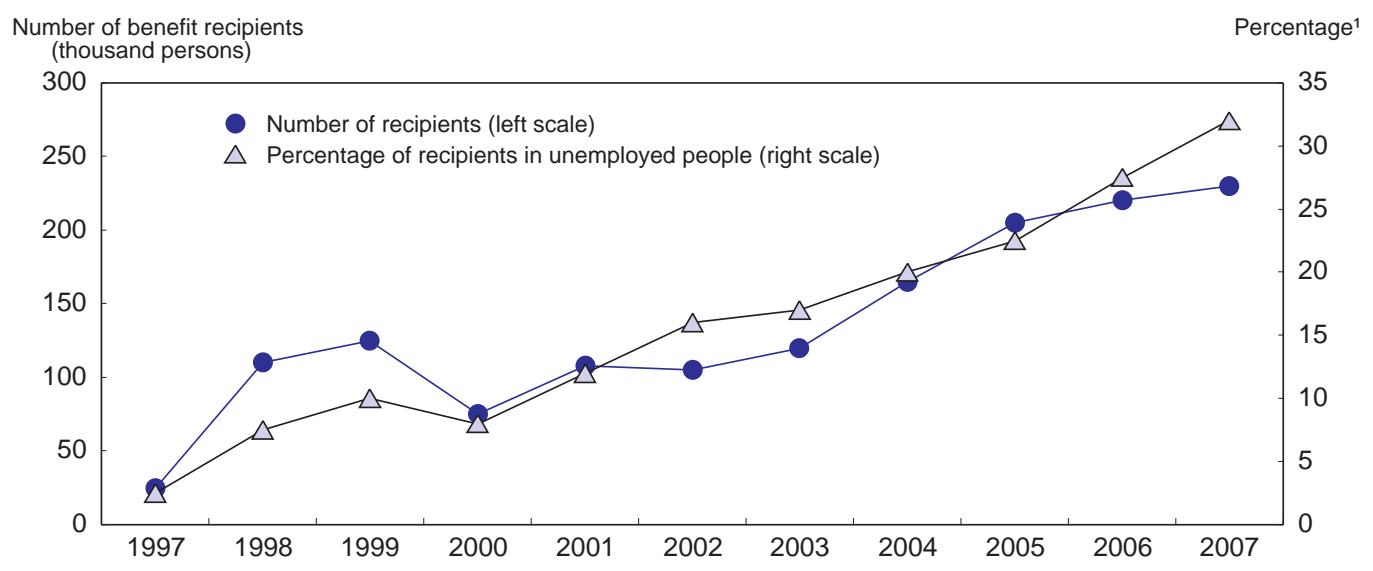

1. As a share of total unemployed.

Source: Korea Labor Review, March-April, 2009.

\section{Policies to address labour market dualism}

39. Five years after the labour law reform, the share of non-regular workers remains high at one-third and job instability has increased. The government announced legislation in 2009, which is still pending, to relax the 2007 reform by extending the maximum length of employment for fixed-term workers from two to four years. Such a reform would reduce job instability by reducing the turnover of fixed-term workers and the concentration of workers in more vulnerable types of non-regular employment. In addition, the government proposed an increase in the number of sectors and job categories in which temporary worker agencies are allowed to operate, given criticism from firms that current laws are too restrictive (KEF, 2011). The government should replace the "positive-list system", which limits such workers to certain occupations and industries, to a "negative-list system", which allows them in general, except in certain cases. Although lengthening the limit for using non-regular workers will benefit firms and promote employment stability, it will not address the dualism problem.

40. The government announced in September 2011 the "Comprehensive Non-regular Workers Initiative" to address dualism, primarily by strengthening the social safety net and enhancing equal treatment for non-regular workers:

i. Subsidising SME contributions to social insurance systems to expand the coverage of their employees, including non-regular workers. Subsidies, set at one-third of the contributions to the EIS and NPS, will be given for employees who work at least 15 hours a week in a firm with fewer than five workers and earn no more than $120 \%$ of the minimum wage.

ii. Strengthening employment conditions, in part by better enforcing the minimum wage and by broadening the coverage of social insurance to include special types of employment, such as delivery vehicle drivers.

iii. Expanding vocational training opportunities for non-regular workers and promoting the transition to regular employment.

iv. Upgrading the inspection of labour conditions to encourage balanced treatment of regular and nonregular workers. 
While this initiative will help improve conditions for non-regular workers, breaking down dualism requires a comprehensive approach that weakens the incentives that encourage firms to hire non-regular workers, notably by relaxing employment protection for regular workers, expanding the social insurance coverage of non-regular workers by improving compliance and increasing training opportunities to enhance their employment prospects.

\section{Relax employment protection}

41. A key is to relax effective employment protection for regular workers to lower its cost so that firms can achieve their desired flexibility without depending as much on non-regular workers. Although Korea has promoted labour market flexibility since the 1997 Asian crisis, the OECD index of employment protection for regular workers in 2008 was 2.3, compared to the OECD average of 2.1. Moreover, it was far above countries such as the United States (0.6), Canada (1.2) and the United Kingdom (1.2). ${ }^{10}$ Recent OECD research shows that increasing employment protection has a significantly negative impact on GDP per capita, with no conclusive impact on total labour income equality (OECD, 2012).

42. Moreover, employment protection for regular workers is exacerbated by its ambiguity. The 1998 revision of the labour law to allow collective dismissals for "urgent managerial reasons" has not sufficiently enhanced flexibility in practice, in part, due to certain requirements. In particular, firms must exhaust "all means" to avoid dismissals on economic grounds and discuss proposed dismissals for at least 50 days with workers in an effort to avoid them. In addition, for dismissals based on "managerial reasons", the firms must send a report to the Minister of Employment and Labour 30 days in advance, which includes the reason of dismissal, issues discussed with worker representatives, and a dismissal schedule. The unpredictability of the strong procedural requirements boosts the cost and uncertainty for firms, thus discouraging them from hiring regular workers. Indeed, international evidence suggests that the creation of temporary jobs is a common response by firms to high costs of reducing permanent jobs (Kahn, 2010). Changing the labour law to accelerate and simplify the procedures would enhance employment flexibility. In addition, reducing uncertainty by clearly specifying the compensation required for dismissed workers in Korea would increase predictability. In 2008, 22 OECD countries required payments for dismissed workers, ranging from eight weeks of salary to 20 months for a worker with 20 years of tenure.

\section{Expand social security insurance coverage}

43. The liberalisation of employment protection should be accompanied by increased coverage of non-regular workers by workplace-based social insurance systems. Many non-regular workers and their firms choose not to participate in social insurance schemes, given the high financial burden and frequent job changes. While the coverage of social insurance is increasing, further efforts to ensure compliance with social insurance premium payments, notably at small firms, are needed. Such measures would narrow the gap in labour costs between regular and non-regular workers, thus reducing incentives to hire non-regular workers, while improving their welfare. As noted above, having the National Tax Service collect social insurance contributions would increase compliance.

\section{Increase opportunities for vocational training}

44. It is important to increase training opportunities for non-regular workers as firms invest less in their training. Expanded vocational training and career consultation outside firms would enhance the

10. The OECD index of the strictness of employment protection legislation for regular employment covers eight indicators related to the procedures involved in individual dismissal, such as the prior notification requirement, severance pay provision, and remedial measures for an unfair dismissal. It runs from 0 (least restrictive) to 6 (most restrictive). 
employment prospects of non-regular workers and facilitate their transition to regular status. Indeed, one study reported that the probability of making the transition from non-regular to regular jobs is significantly higher for non-regular workers who attend training programmes (KDI, 2009). In 2011, the "My Work Learning Card System", an individual training account that was available only to unemployed persons, was extended to non-regular workers to expand their training opportunities.

\section{Reforms in the education system to promote social cohesion}

45. In 1945 , Korea's literacy rate was $22 \%$ and less than $20 \%$ of children attended secondary school. Thanks to large public investment in schools, enrolment rates reached $90 \%$ for primary school in 1964 , for middle school in 1979 and high school in 1993. In addition to boosting economic growth, the emphasis on universal access to primary and secondary schools promoted social mobility and income equality (Koh et al., 2010). However, some aspects of the education system today should be improved, given that policies that promote equal access to education help reduce inequality (OECD, 2012). First, greater investment in early childhood education and care (ECEC) would provide a better educational foundation for children from low-income households. Second, the widespread use of private tutoring, notably in private institutions known as hagwons, perpetuates inequality. Third, the low level of student loans and grants despite high tuition fees limits the access of students from low-income households to high-quality tertiary education. This section discusses reforms in each of these areas to improve equity.

\section{Improving access to high-quality early childhood education and care}

46. Childcare and kindergartens enrolled $61.6 \%$ of the under-six age group by 2009 (Table 5). The enrolment rate in childcare peaks at $54.4 \%$ for two-year-olds, then falls as an increasing share of children switch to kindergarten. For the three-to-five age group, enrolment is evenly split with about $40 \%$ each attending childcare and kindergarten. The two systems remain segmented, with separate facilities and different objectives and curricula (Rhee et al., 2008). The educational quality of kindergarten, under the Ministry of Education, Science and Technology (MEST), is considered superior to that of childcare, which is administered by the Ministry of Health and Welfare (MHW) and has more of a social-welfare orientation. In a survey of parents, $78 \%$ replied that there are significant differences between kindergarten and childcare, with educational content and programmes the most important (Yoo et al., 2008).

Table 5. Enrolment in childcare and kindergarten Thousand children in 2009

\begin{tabular}{cccccccc}
\hline Age & $\begin{array}{c}\text { Number of } \\
\text { children } \\
(\mathrm{A})\end{array}$ & $\begin{array}{c}\text { Childcare } \\
(\mathrm{B})\end{array}$ & $\begin{array}{c}\text { Rate } \\
(\mathrm{B} / \mathrm{A})\end{array}$ & $\begin{array}{c}\text { Kindergarten } \\
(\mathrm{C})\end{array}$ & $\begin{array}{c}\text { Rate } \\
(\mathrm{C} / \mathrm{A})\end{array}$ & $\begin{array}{c}\text { Total enrolled } \\
(\mathrm{B}+\mathrm{C} / \mathrm{A})\end{array}$ & $\begin{array}{c}\text { Employment rate } \\
\text { of mothers }\end{array}$ \\
\hline 0 & 424.5 & 107.5 & 25.3 & 0.0 & 0.0 & 25.3 & 24.7 \\
1 & 464.3 & 198.8 & 42.8 & 0.0 & 0.0 & 42.8 & 29.2 \\
2 & 492.5 & 268.0 & 54.4 & 0.0 & 0.0 & 54.4 & 39.2 \\
$0 \sim 2$ & 1381.3 & 574.4 & 41.6 & 0.0 & 0.0 & 41.6 & 29.9 \\
\hline 3 & 447.4 & 228.0 & 50.9 & 111.5 & 24.9 & 75.9 & 44.4 \\
4 & 434.7 & 193.9 & 44.6 & 181.4 & 41.7 & 86.4 & 44.8 \\
5 & 473.1 & 152.4 & 32.2 & 244.7 & 51.7 & 83.9 & 46.0 \\
$3 \sim 5$ & 1355.2 & 574.3 & 42.4 & 537.6 & 39.7 & 82.0 & 44.9 \\
\hline $\mathbf{0 ~ 5}$ & $\mathbf{2 7 3 6 . 5}$ & $\mathbf{1 1 4 8 . 7}$ & $\mathbf{4 2 . 0}$ & $\mathbf{5 3 7 . 6}$ & $\mathbf{1 9 . 6}$ & $\mathbf{6 1 . 6}$ & $\mathbf{3 5 . 8}$ \\
\hline
\end{tabular}

Source: Suh and Kim (2010).

47. Total spending on pre-primary education in Korea was the second lowest in the OECD area in 2008 , with the public sector accounting for less than half, well below the OECD average of $82 \%$ (Figure 9). Public spending on childcare amounted to $0.4 \%$ of GDP in 2009, below the OECD average of 
0.6\%. Private institutions play the dominant role in ECEC, accounting for $89 \%$ and $77 \%$, respectively, of childcare and kindergarten enrolments in 2009. Quality is higher, though, in public institutions.

48. The tuition fees for ECEC vary widely between institutions and regions, as the 16 metropolitan city and provincial governments set fees for public institutions and impose fee ceilings on private childcare centres. In Seoul, for example, monthly basic fees in 2010 for four and five-year-olds ranged from 115 thousand won (around \$100) for public kindergartens to 172 thousand won for public childcare, 238 thousand won for private childcare and up to 540 thousand won for private kindergartens, which do not face price ceilings. The government has been steadily increasing ECEC subsidies to families:

- Eligibility for the means-tested subsidies introduced in 1991 was gradually expanded to cover the lower $70 \%$ of the income distribution by 2009 , with the subsidy covering between $30 \%$ and $100 \%$ of basic childcare fees (Suh and Kim, 2010). For children eligible for the $100 \%$ subsidy, childcare fees were reduced to $4.6 \%$ of household income, compared to $9.6 \%$ for those with incomes too high for subsidies (Table 6). In 2011, the subsidy was raised to $100 \%$ of basic fees for all households in the lower $70 \%$ of the income distribution.

- The government's 1997 goal to provide support for all five-year olds regardless of family income was achieved in 2012. It recently announced an objective of extending such support to all three and four-year-olds beginning in 2013.

Figure 9. International comparison of private spending on education in 2008

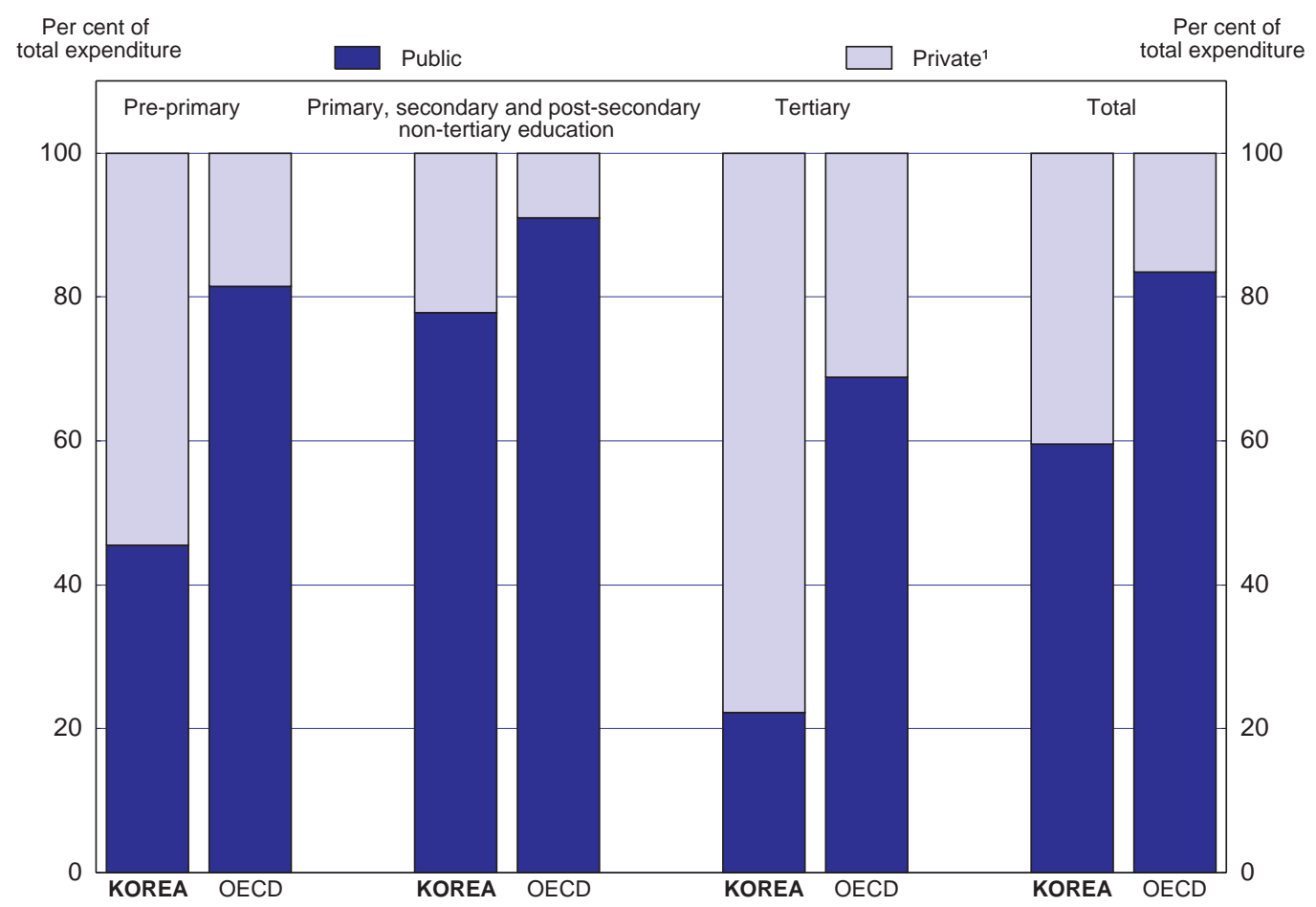

1. For primary, secondary and tertiary education, based on full-time equivalents. The figures do not include spending on private after-school institutions, such as hagwons.

Source: OECD (2011c), OECD Education at a Glance 2011.

49. Most families receiving the means-tested subsidies send their children to childcare centres, reflecting several factors: $i$ ) they are considerably cheaper than private kindergarten, whose basic fees run 
as high as three times the government subsidy, which is based on public childcare; ii) there is a lack of capacity in public kindergartens; iii) childcare centres tend to be more conveniently located because there are more than four times as many childcare centres as kindergartens; and $i v$ ) they are more convenient for working parents as they have longer hours and stay open year-round, in contrast to kindergartens, which operate about 180 days a year. As a result, families at lower socioeconomic levels and working mothers tend to resort to childcare, while middle and upper-income families tend to place their children in kindergarten and hagwons (Yun, 2009), thus perpetuating inequality.

Table 6. Childcare fee by exemption status

Thousand Korean won and per cent in 2009

\begin{tabular}{|c|c|c|c|c|c|}
\hline Fee status & $\begin{array}{l}\text { Share of } \\
\text { children }\end{array}$ & Basic fee & $\begin{array}{l}\text { Additional } \\
\text { fees }\end{array}$ & Total cost & $\begin{array}{c}\text { Share of } \\
\text { household income }\end{array}$ \\
\hline Exempted $^{1}$ & 35.0 & 10.7 & 44.3 & 55.0 & 4.6 \\
\hline Reduced & 36.0 & 108.5 & 56.7 & 165.2 & 7.8 \\
\hline General & 29.0 & 246.8 & 61.8 & 308.6 & 9.6 \\
\hline Total & 100.0 & 114.3 & 53.8 & 168.1 & 7.4 \\
\hline
\end{tabular}

1. Parents still pay some basic fees as the cost at some private childcare institutions exceeds the amount of the subsidy.

Source: Suh and Kim (2010).

50. A large number of children attend hagwons, instead of or in addition to childcare and kindergarten. Hagwons are primarily focused on academic subjects, particularly foreign languages and mathematics, reflecting intense competition beginning at a young age. Indeed, providing "differentiated programmes to help distinguish one's children from other children" was the main reason, cited by nearly half of parents in a survey in Seoul and Gyeonggi, for enrolling children in hagwons rather than childcare and kindergarten (Lee et al., 2009). Another survey found that the average age for beginning English classes is 3.7 years in Seoul and Gyeonggi province, with some children beginning before age two (Korea Herald, 30 August 2011). The emphasis on starting education at an early age stands out even relative to other Asian countries (Child Research Net, 2010).

51. The exceptionally low level of public spending on ECEC in Korea and the high share of private outlays makes the quality of ECEC dependent on a household's income level, thus limiting the opportunities for low-income children. Consequently, children enter primary school with varying levels of education. While the drive to provide support for ECEC to all children aged three to five promotes higher enrolment and eases the burden on families, it does not create equal opportunities for high-quality educational opportunities, which would instead require other policies. First, increasing the capacity of public kindergartens would improve access for low-income families. The 2010 revision of the kindergarten law allows kindergartens to be attached to primary or secondary schools. With falling enrolments, schools presumably will have empty classrooms that could be used for kindergartens. Moreover, it should be mandatory for new primary schools in urban areas to include kindergartens. Second, higher tuition subsidies for low-income families would improve their access to private kindergartens. ${ }^{11}$

\section{Reducing the reliance on private tutoring: addressing the issue of hagwons}

52. After-school education has been a major factor behind the excellent performance of Korean students in international tests, such as PISA (Koh et al., 2010). In 2010, around three-quarters of students participated in such courses (Table 7). According to the PISA assessment of 15-year-old students, the

11. Policies to upgrade the overall quality of ECEC are discussed in Chapter 1 of the 2012 OECD Economic Survey of Korea. 
participation is more than double the OECD average in every subject (Figure 10). Indeed, Korea ranks first in the share of students studying mathematics and science and second (after Japan) in national language. Academic subjects account for four-fifths of private tutoring with the remainder divided between music, art and sports. Among academic subjects, English (41\%), mathematics (35\%) and Korean (11\%) were the most important. More than $70 \%$ of students participating in private tutoring attend hagwons, making it the most important player in this sector. It is not uncommon for students to be enrolled in several hagwons focusing on different subject areas. Korea currently has nearly 100 thousand hagwons, which must receive a permit from the local education government to operate. The concentration of around 6000 hagwons in the Kangnam district of Seoul is thought to be an important factor in the high housing prices in that area, which has become a major social issue. The hagwons have more teachers than the public school system and attract the best ones with higher salaries. Admission to prestigious hagwons is challenging and depends on entrance exams. ${ }^{12}$ In addition to hagwons, private tutoring includes individual or group tutoring and Internet and distance learning.

53. Total spending on private tutoring in 2010 fell 3.5\% in nominal terms from 2009, reflecting a decline in participation from $75.0 \%$ of students to $73.6 \%$. Outlays per student participating in private tutoring, though, rose by $1.2 \%$. Total spending increased from $1.2 \%$ of GDP in 1999 (Ministry of Education, 2000) to $1.8 \%$ in 2010 , representing $7.9 \%$ of average household disposable income (Table 7). A family with three children could thus spend a quarter of their income on private tutoring (Box 1).

Figure 10. The percentage of students attending after-school lessons in Korea is exceptionally high

By hours per week in 2009
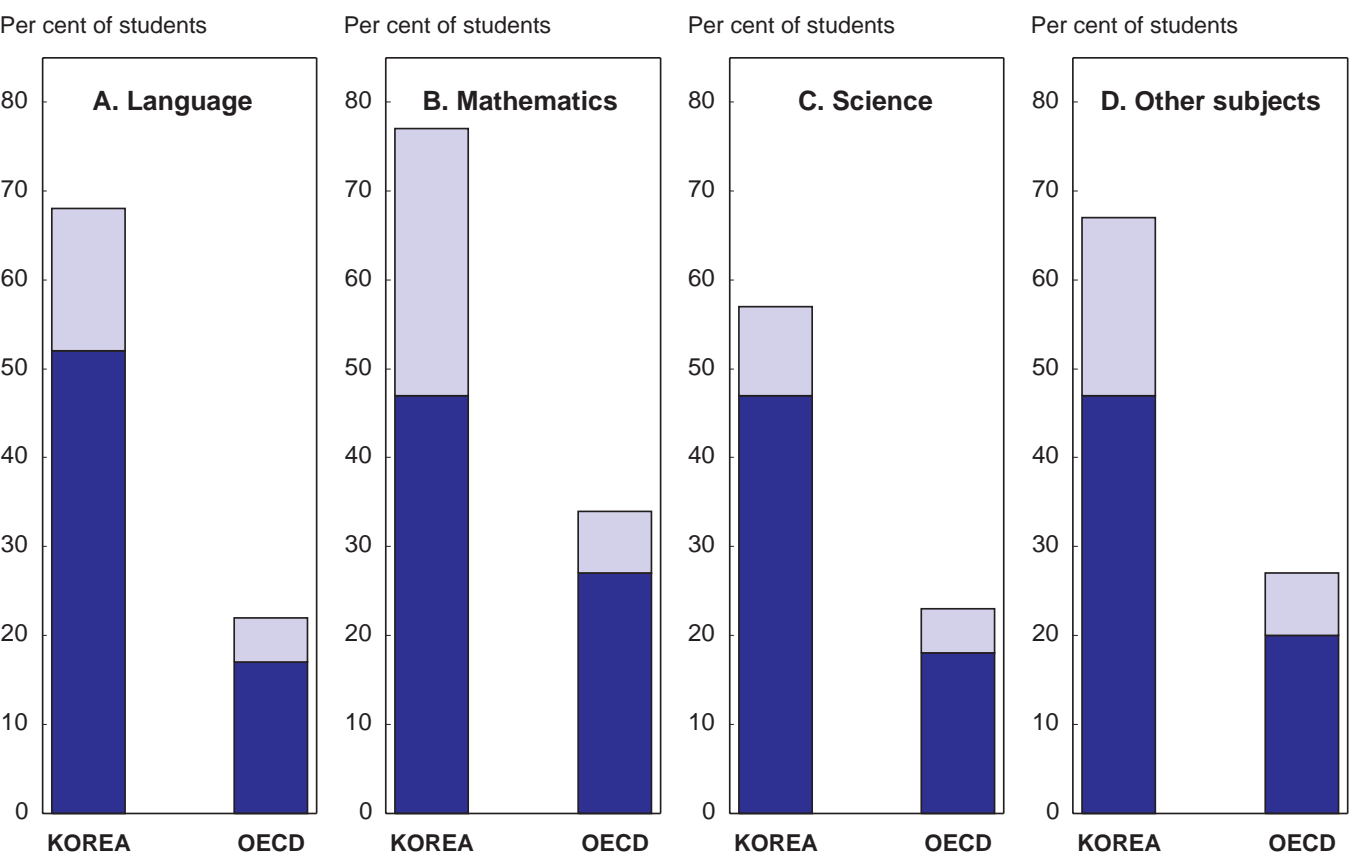

Source: OECD (2010c).

12. Only $14 \%$ of applicants for the Daesung Institute are accepted. After one year of study, $70 \%$ gain entrance to one of Korea's top three universities (Time Magazine, 3 October 2011). 
ECO/WKP(2012)40

Table 7. Private, after-school education in Korea in 2010

\begin{tabular}{lc|cc|cc|cc}
\hline & $\begin{array}{c}\text { Participation } \\
\text { rate } \\
(\%)\end{array}$ & $\begin{array}{c}\text { Expenditure } \\
\text { per } \\
\text { student }^{1}\end{array}$ & $\begin{array}{c}\text { Share } \\
\text { of } \\
\text { income }^{2}\end{array}$ & $\begin{array}{c}\text { Expenditure } \\
\text { per } \\
\text { student }^{3}\end{array}$ & $\begin{array}{c}\text { Share } \\
\text { of } \\
\text { income }\end{array}$ & $\begin{array}{c}\text { Total } \\
\text { expenditure } \\
\text { (trillion } \\
\text { won) }\end{array}$ & $\begin{array}{c}\text { Share } \\
\text { of } \\
\text { GDP } \\
(\%)\end{array}$ \\
\cline { 2 - 7 } Total & 73.6 & 240 & 7.9 & 325 & 10.7 & $\mathbf{2 0 . 8}$ & 1.8 \\
Primary school & 86.8 & 245 & 8.1 & 282 & 9.3 & 9.7 & 0.8 \\
Middle school & 72.2 & 255 & 8.4 & 352 & 11.6 & 6.0 & 0.5 \\
High school & 52.8 & 218 & 7.2 & 408 & 13.4 & 5.1 & 0.4 \\
General high school & 62.0 & 265 & 8.7 & 433 & 14.3 & 4.8 & 0.4 \\
Vocational high school & 33.7 & 67 & 2.2 & 246 & 8.1 & 0.4 & 0.0 \\
\hline
\end{tabular}

1. For all students in thousand won per month, regardless of whether they participated in private, after-school education.

2. As a per cent of average household disposable income, based on 2.84 persons per household.

3. Per student that participates in private, after-school education in thousand won.

Source: Ministry of Education, Science, and Technology (2011).

\section{Box 1. Why parents send their children to private, after-school lessons}

A 2010 government survey asked parents the reasons for high spending on private tutoring (Table 8).

- The most common answers focused on the difficulty and importance of gaining entry to prestigious universities, which select students primarily based on entrance exam scores. Academic credentialism - the emphasis on where a person studied rather than on their abilities, accomplishments and potential - is strong in Korea, based on a well-known ranking of universities (Chang, 2009).

- $\quad$ Parents are increasingly well educated and have high expectations for their children. With the fall in the birth rate and rising incomes, they have more resources to spend per child.

Table 8. Reasons for increasing private tutoring

Five-point scale ${ }^{1}$

\begin{tabular}{clr}
\hline Rank & \multicolumn{1}{c}{ Reasons } & Score \\
\hline 1 & The name of the university one graduates from is important for future job prospects & 4.2 \\
1 & Special purpose high schools and universities select students based primarily on their test scores & 4.2 \\
3 & Universities have a severe ranking system for admission & 4.1 \\
4 & Parents have higher expectations for their children as they have higher levels of education and & \\
& fewer children due to the low birth rate & 3.0 \\
5 & School tests are more difficult than what students learn in regular classes & 3.9 \\
5 & School education alone cannot develop students' potential and aptitude & 3.7 \\
5 & Not participating in hagwons worries parents and students, given that hagwons are so prevalent & 3.7 \\
5 & Economic growth and higher incomes facilitate increased spending & 3.7 \\
9 & Schools fail to provide tailored learning support to individual students & 3.4 \\
9 & Schools fail to provide lectures that are differentiated according to students' academic level & 3.3 \\
9 & Schools provide insufficient support for academic progress, counselling and information & 3.3 \\
12 & Classroom atmosphere and school equipment are not satisfactory & 2.7 \\
\hline
\end{tabular}

1. Survey that asked parents to rank factors responsible for the increase in private tutoring.

- The weakness of schools is cited in five of the top responses. In particular, schools are criticised for failing to fully develop students' potential, providing insufficient academic support and individualised teaching and having an unsatisfactory atmosphere. The deterioration of the classroom environment has become a widely 


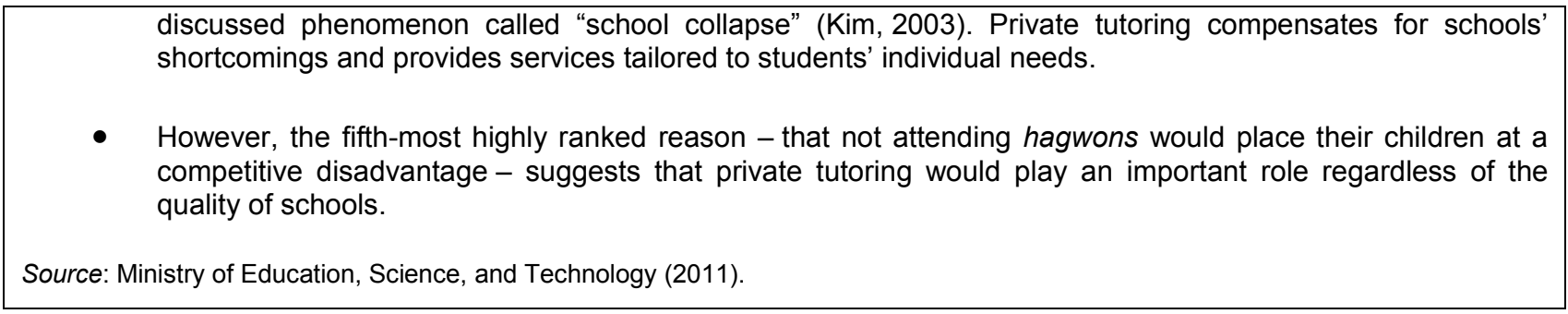

54. Participation in private tutoring by students in the top $30 \%$ of their class is over $80 \%$, compared to less than $50 \%$ in the bottom $20 \%$ (Table 9). Moreover, outlays per student for the upper group are more than double those for the lower group. In short, participation in private tutoring appears to contribute to successful educational outcomes for parents able and willing to purchase such services for their children.

Table 9. Participation and spending in private tutoring rises with academic performance

\begin{tabular}{c|ccc|ccc}
\hline $\begin{array}{c}\text { Student's } \\
\text { class ranking }\end{array}$ & \multicolumn{3}{|c|}{$\begin{array}{c}\text { Participation in private tutoring } \\
\text { (Per cent) }\end{array}$} & \multicolumn{2}{c}{ Spending per student $^{1}$} \\
\hline & 2009 & 2010 & Change $^{2}$ & 2009 & 2010 & Change $^{2}$ \\
\cline { 2 - 7 } Top 10\% & 87.0 & 85.3 & -1.7 & 319 & 317 & -0.6 \\
$11 \sim 30 \%$ & 84.9 & 83.9 & -1.0 & 283 & 282 & -0.4 \\
$31 \sim 60 \%$ & 75.3 & 73.8 & -1.5 & 232 & 233 & 0.4 \\
$61 \sim 80 \%$ & 60.7 & 59.8 & -0.9 & 184 & 182 & -1.1 \\
Bottom 20\% & 50.4 & 48.8 & -1.6 & 139 & 136 & -2.2 \\
Total & $\mathbf{7 5 . 0}$ & $\mathbf{7 3 . 6}$ & $\mathbf{- 1 . 4}$ & $\mathbf{2 4 2}$ & $\mathbf{2 4 0}$ & $\mathbf{- 0 . 8}$ \\
\hline
\end{tabular}

1. Monthly outlays on private tutoring per student (all students, including those not involved in such education) in thousand won.

2. In percentage points.

Source: Ministry of Education, Science and Technology (2011).

55. Participation and spending on private tutoring are highly correlated with family income (Figure 11). Only $36 \%$ of students from families with a monthly income of less than 1 million won participated in private tutoring, compared to $80 \%$ for those from families earning 3 to 4 million won. Similarly, the amount of outlays per student in private tutoring is four times higher for the middle-income group than those in the lowest-income group. For households with income over 6 million won per month, enrolment rates rise to nearly $90 \%$, while outlays per month reach around 450 thousand won (around \$400).

56. While Korea places a high value on egalitarianism, policies to promote equal opportunity are undermined by the heavy reliance on private tutoring to enter high-ranking universities, which has an inordinate impact on job prospects and future income (Kim and Lee, 2003). The higher participation and spending on private tutoring thus allows family income to determine access to higher education, creating cycles of poverty and wealth that endure over generations.

- The poorer a student's background, the more likely he or she is to attend college rather than university.

- The dropout rate from college ( $8 \%)$ is double that for university $(4 \%)$.

- A student with a better socioeconomic background is more likely to enter a prestigious university and study a subject that he or she would like to. One study found that $16.9 \%$ of students from the 
upper-middle income class attended upper-level universities compared to only $5.8 \%$ for lowerclass students. For lower-level universities, the situation is reversed, with a much larger share of students from lower-income class households (KEDI, 2006).

While the expansion of tertiary education opened the door to higher education for a larger share of the population, low-income students are concentrated in the low-ranking universities. It is important to address this source of inequality.

\section{Figure 11. Household income and participation and spending on private tutoring in 2010}
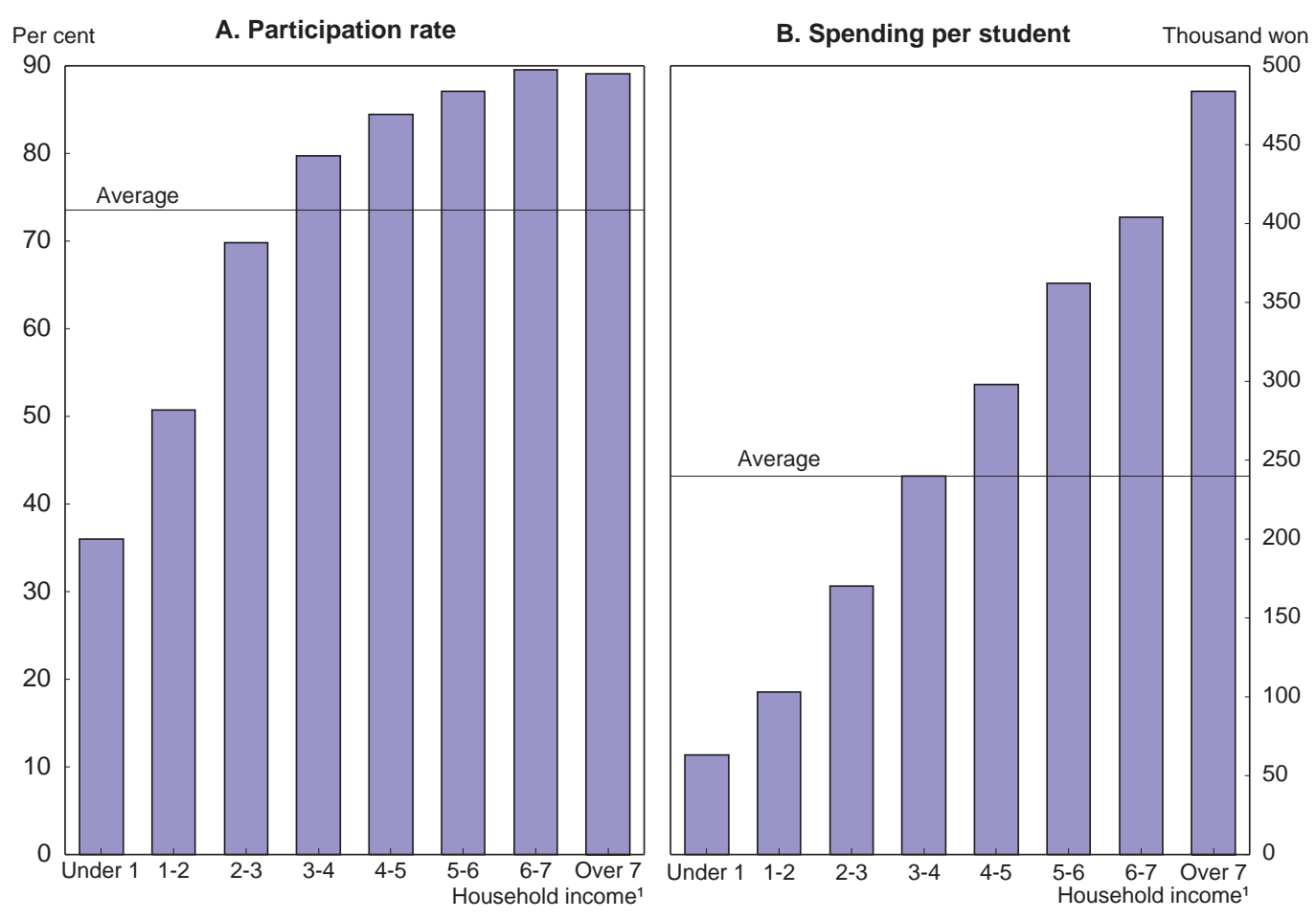

1. In million won per month.

Source: Ministry of Education, Science, and Technology (2011).

57. In addition to the heavy financial burdens on families from private tutoring and the impact on equality, there are a number of other disadvantages. First, to the extent it duplicates school curricula, private tutoring absorbs resources that could be used more efficiently elsewhere. Second, even in Seoul, where there is a 10 p.m. curfew for hagwons, private tutoring tends to unduly dominate children's lives and restrict their leisure activities in ways that are detrimental to their well-rounded development. Third, private tutoring disrupts schools and undermines them by allowing some students to move ahead of their classmates, thus reducing their interest in school (Bray, 2009). Indeed, nearly half of students participating in private tutoring said that one of the reasons was to have access to advanced studies. These problems explain why private tutoring has been described as the "enemy of the public school system" (Chung, 2002).

\section{Policies to reduce reliance on hagwons and other forms of private tutoring}

58. The government has long tried to limit the role of hagwons and other forms of private tutoring. One of the first steps was the equalisation policy, which attempted to end "entrance exam hell" by abolishing competitive exams for middle school in 1969, and for high school in 1974. Instead, students in 
urban areas were allocated to schools in their district by a lottery system, thus eliminating a major reason for sending children to hagwons. In 1980, the government banned hagwons and other private tutoring on the grounds that they unfairly burdened the poor and promoted inequality. Students receiving tutoring could be suspended from school. While the reforms were generally welcomed by students and parents, the continued pressure to succeed academically simply drove the private tutoring industry underground. The ban was finally ruled unconstitutional by the Supreme Court in 2000 on the grounds that it "infringes on the basic rights of the people to educate their children". The government launched a five-year plan to improve the quality of schools by boosting the number of teachers and their salaries, purchasing computers and expanding English classes to compete with private tutoring. Despite the Supreme Court ruling, there have been subsequent attempts to limit private tutoring. In 2008, for example, there were measures to limit the cost of hagwons and Seoul imposed a 10 p.m. curfew on hagwons.

59. To achieve the government's goal of significantly reducing private tutoring, a number of policies are necessary, beginning with the criteria for university admission, including the College Scholastic Aptitude Test (CSAT). A major purpose of hagwons is to prepare students for the multiple-choice CSAT exam, which accounts for $70 \%$ of a student's high school ranking, compared to only $10 \%$ for the student's high school record (OECD, 2009). Reducing the importance of the CSAT in university admissions would thus reduce reliance on hagwons. Under the new "admissions officer" system to select university students, greater weight is given to other criteria, such as recommendations, essays and extra-curricular activities, as well as school grades in order to reform the test score-based admission practice. It will take time for the admissions officer system to gradually change students' mind sets over the long run. There is a need for caution, though, as a reliance on more subjective criteria opens up opportunities for favouritism and corruption, given the importance of social connections. The reliance on multiple-choice exams has provided legitimacy to the university entrance process.

60. The government survey discussed above also asked parents which policies would reduce spending on private tutoring (Table 10). First, a number of responses focused on improving the quality of schools, as it would enable students to acquire sufficient education without participating in private tutoring. Specific areas for improvement included strengthening the creativity and character-building aspects of schools, improving the teaching of English, better supporting underachieving students and using teacher evaluation systems. Second, parents noted the importance of creating diverse schools, an objective the government is pursuing through its plan to establish 300 "autonomous" high schools. Third, strengthening vocational education and career guidance would reduce private tutoring. This is also supported by the second-ranked objective of "changing students' and parents' view of education and giving more access to information". Fourth, providing all-day kindergartens would reduce reliance on hagwons for child care.

61. The parent survey also suggested using tracking - separating students by ability levels - as a way of meeting the needs of individuals and reducing outlays for private tutoring. However, tracking, particularly at a young age, tends to increase inequality in educational outcomes (OECD, 2010a). Finally, there is support for stabilising hagwon fees. Given that hagwons are private enterprises providing heavily demanded services, government measures to limit their fees are likely to be difficult to implement.

\section{Making after-school lessons more accessible to low-income students}

62. Even with reforms, private tutoring will continue to play a significant role, making it important to provide its benefits more broadly and at lower cost. The government survey discussed above mentioned three alternatives. First, on-line education systems are a rapidly growing component of the private tutoring service industry in many countries (Ventura and Jang, 2010) and tend to be much less expensive. In Korea about one-third of students participating in private tutoring use Internet lessons, including those offered by hagwons, and the government's Cyber Home Learning. The system, which has three million users, with 228 thousand visits per day, could be further expanded. The government estimates that it reduced private 
tutoring spending by 1.1 trillion won (5\% of actual spending) in 2011. Second, the public Educational Broadcast System, established in 1990, provides lectures to high school students preparing for the university admission exam. This system had 3.9 million users in 2011, with about 694 thousand visits per day, cutting private tutoring spending by another 816 billion won.

Table 10. Policies that would reduce spending on private tutoring

Five-point scale ${ }^{1}$

\begin{tabular}{clr}
\hline Rank & & \multicolumn{1}{c}{ Policy } \\
\hline 1 & Use tracking to separate students into classes based on their academic ability & 4.0 \\
2 & Changing students' and parents' view of education and giving more access to information & 3.9 \\
2 & Creating good and diverse schools & 3.9 \\
2 & Strengthening the creativity and character-building aspects of education & 3.9 \\
2 & Stabilising tuition fees of hagwons & 3.9 \\
6 & Strengthening the teaching of English in public schools & 3.8 \\
6 & Supporting underachieving students & 3.8 \\
8 & Using on-line educations systems & 3.7 \\
8 & Teacher evaluation systems & 3.7 \\
8 & Disclosure of school information & 3.7 \\
11 & Revitalising after-school programmes & 3.6 \\
11 & Strengthening vocational education and career guidance & 3.6 \\
11 & Supporting customised education service using IPTV & 3.6 \\
14 & Moving students to different classrooms according to their achievements level & 3.5 \\
15 & during regular school hours & 3.4 \\
\hline
\end{tabular}

1. Survey that asked parents to rank policies that would reduce spending on private tutoring. Source: Ministry of Education, Science, and Technology (2011).

63. In addition, the after-school programmes offered at virtually all primary and secondary schools could be further expanded to reduce outlays on private tutoring. The number of students participating in such programmes (both free and paid) rose from 43\% when they were introduced in 2006 to $65 \%$ in 2011, with higher rates for low-income families and those in rural areas, who have less access to hagwons. Twothirds of the instruction is provided by school teachers, who offer lessons that could not be covered in regular classes (Kim, 2010). An OECD study found that after-school classes with a teacher can enhance equity, in contrast to such classes with teachers from the outside (OECD, 2011e). Eight of the 16 metropolitan and provincial offices of education allow the programmes to be contracted out to for-profit organisations. Spending on private tutoring was reduced from an average of 3.5 million won to 3.0 million won for students participating in after-school lessons in schools.

\section{Reducing the burden of tertiary education}

64. The public-sector share of spending on tertiary education was only $22 \%$ in 2008 , well below the OECD average of $69 \%$. Private institutions, which account for around three-quarters of students, depend primarily on tuition fees. Consequently, tuition fees at private universities were the third highest in the OECD area at \$9 586 (PPP exchange rates) in the 2008-09 academic year (Figure 12). Fees at the most expensive institutions were about double those at the least expensive. Although public university fees are lower at $\$ 5315$, they are still the third highest among OECD countries. At the same time, government scholarships and grants to students (6.0\% of public spending on education) and student loans $(5.4 \%)$ were well below the OECD averages of $11.4 \%$ and $8.8 \%$, respectively (OECD, 2011a). In total, public subsidies to households for tertiary education in the 2008-09 academic year amounted to $0.1 \%$ of GDP, only one- 
third of the OECD average of $0.3 \%$ and the fifth lowest in the OECD. Consequently, a student's socioeconomic background is significantly correlated with the quality of the tertiary institution that he or she attends. University tuition has become one of the most heated political issues in Korea. Student protests in 2011 coalesced around the slogan "half-price tuition". In June 2011, the ruling party proposed cutting tuition fees by $30 \%$ by 2014. In 2012, fees are to be reduced by $15 \%$ through 1.5 trillion won of government spending and requiring universities to increase grants by 0.5 trillion won.

Figure 12. International comparison of university tuition fees ${ }^{1}$

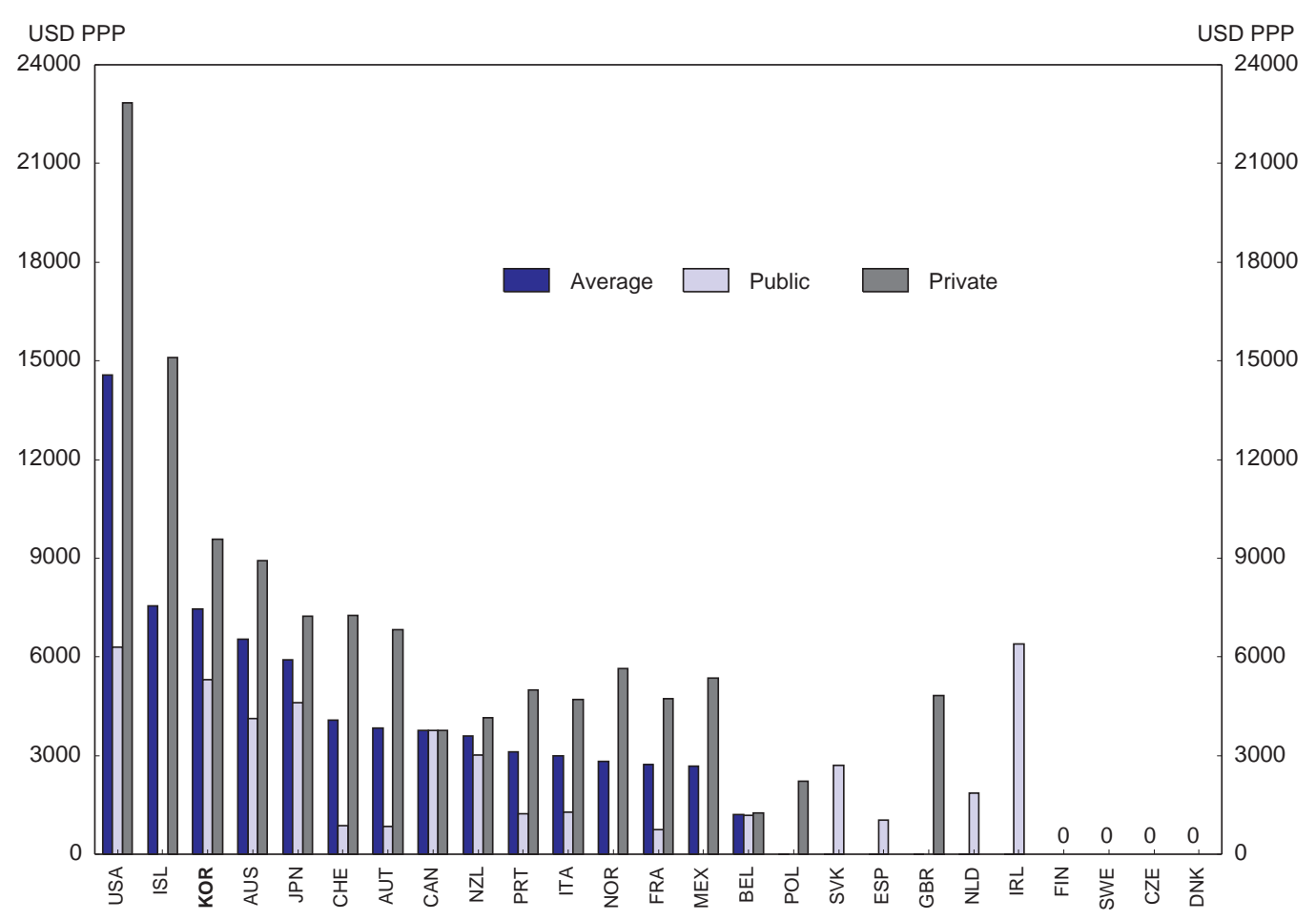

1. Full-time students at tertiary type A institutions in 2008-09. Tuition fees are not adjusted for fee waivers granted by institutions or for tax treatment of tuition fees.

Source: OECD (2011c), OECD Education at a Glance 2011.

65. The government has already taken several steps to address the tuition issue. First, the government put a ceiling on increases in university tuition beginning in 2011; the percentage increase in tuition cannot be more than 1.5 times higher than the average increase of the consumer price index during the previous three years. Second, it required universities to organise a tuition review committee that includes professors and students. Third, the government established the Korean Student Aid Foundation in 2009 to provide means-tested grants and to administer the major government-sponsored student loan schemes. The share of university students receiving scholarships because of their low-income background increased from $3.1 \%$ in 2009 to $4.4 \%$ in 2011 . The amount per student, though, was less than one-half of the average tuition at a private university. The 2012 reform of the scholarship programme to reduce the burden of tuition fees created two types of grants, ${ }^{13}$ boosting outlays from 335 billion won to 1.5 trillion won.

13. Type I will be allocated to low-income students through universities. Students who qualify for the BLSP, the basic welfare programme that covers $3 \%$ of the population, will receive 4.5 million won per year. In addition, other students in the bottom $10 \%$ of the income distribution will receive 2.25 million won. 
66. In addition, the government introduced in 2010 the "Study Now, Pay Later" programme of public loans for undergraduates who meet the grade requirement and are from households below the $70 \%$ income percentile. Repayment of the loan is contingent on post-graduation income, thus helping to overcome the aversion to debt. Meanwhile, the income criteria for the regular government-guaranteed loan scheme, which was introduced in 2005 on a means-tested basis, was abolished, making the loans available to all students who meet the grade criteria. This scheme imposes a fixed-repayment schedule. With the introduction of the income-contingent loan programme, the number of students receiving loans under the regular programme has fallen by more than one-third, but the overall number receiving loans rose by $8 \%$ between the second semesters of 2009 and 2011 (Table 11). In contrast to scholarships, government loans cover more than $80 \%$ of the tuition at private universities.

Table 11. Government-guaranteed loans for university tuition

In billion won in the second semester of academic year

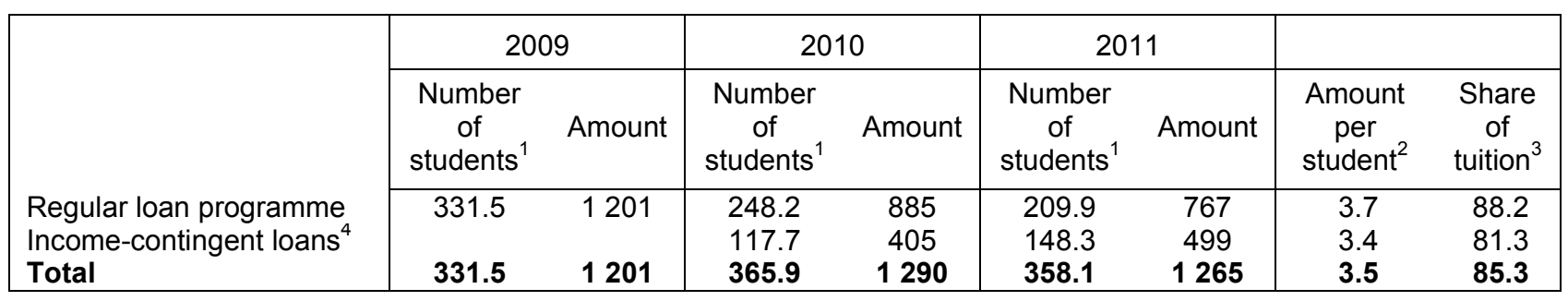

1. In thousands of students.

2. In million won.

3. In 2011. Tuition is calculated from the 2008 figure shown in OECD Education at a Glance, adjusted by the CPI index for 2011.

4. Introduced in $\mathbf{2 0 1 0}$ for students from low-income families. This programme is also referred to as "Study Now, Pay Later".

Source: Ministry of Education, Science and Technology.

67. While politically popular, half-price tuition would have a number of drawbacks. First, universally subsidising tuition fees could lead to even more students going to university, thereby exacerbating the problem of overemphasis on tertiary education and skill mismatches. Second, half-price tuition raises questions about value for money, as it would effectively subsidise low-quality institutions that should instead be restructured or closed. Third, subsidising the tuition fees for all students is less efficient and less equitable than targeting support on students from low-income households, who face larger hurdles in accessing tertiary education. Fourth, it could cost about 7 trillion won $\left(0.6 \%\right.$ of GDP). ${ }^{14}$ Experience in other countries suggests it is very difficult to move away from universal subsidisation of tuition once it is in place. Caution is thus warranted given the long-lasting financial consequences. The government has appropriately sought to reframe the issue as part of a wider reform of the tertiary sector (2012 OECD Economic Survey of Korea).

68. The new income-contingent loan scheme, which is limited to the lower $70 \%$ of the income distribution, should be extended to all students, subject to their satisfactory academic progress. The government recently cut the interest rate on loans, exempted interest payments during military service and eased the grade point average requirement for eligibility. Such reforms should continue to increase access to the income-contingent loan programme. Making reimbursement dependent on post-graduation income is crucial. Otherwise, the loan take-up ratio would be limited by potential students' risk aversion. Moreover,

Type II allows universities to support students in the bottom $70 \%$ of the income distribution based on their self-help efforts.

14. Given that a 15\% reduction would cost 2 trillion won (Korea Herald, 23 June 2011), a 50\% tuition reduction would cost around 7 trillion won, which is about $0.6 \%$ of 2011 GDP. 
some students may otherwise borrow less by taking a shorter, less costly course of study than is optimal. In addition, given the difficulties university graduates face in finding employment, reforms to increase the flexibility of outstanding fixed-repayment student loans would be helpful. At present, around 80000 students are delinquent in their repayments. Moreover, universities need to provide quality education for the scheme to be successful. Otherwise students will not be able to find a good job and earn enough money to pay back their loans. Finally, the government should consider whether the tax deductibility of tuition payments is the most equitable way to lighten the financial burden of tertiary education. Given that only half of the labour force pays income tax, and that many of them that do pay face only a $6 \%$ rate, tax benefits reduce the cost of tertiary education primarily for high-income families.

\section{The service sector as a factor in inequality}

69. Manufacturing's share of employment fell from $28 \%$ in 1990 to $17 \%$ by 2008 , as workers moved to the service sector. The shift was accompanied by a marked fall in the relative wage in services from nearly $100 \%$ of that in manufacturing to only $54 \%$ in 2009 . In addition, there is wide wage dispersion in the service sector, from business services and the financial sector to hotels and restaurants.

70. The low wage and productivity problem is closely linked to SMEs, which account for $80 \%$ of output and $90 \%$ of employment in services. The deteriorating wage performance in services has thus widened the gap between large and small firms (Figure 13). In 1989, workers in firms with 10 to 29 workers earned $24 \%$ less than workers at companies with 300 or more workers. By 2008, the gap had widened to $43 \%$. Consequently, the problem of poverty among workers is concentrated in small companies (Table 12). The incidence of low wages (defined as less than one-half the median wage) falls from $39.1 \%$ of female workers in firms with less than five workers to $4.0 \%$ for companies with more than 1000 . Policies to boost productivity in services and in SMEs are discussed in the 2012 OECD Economic Survey of Korea.

Figure 13. Trends in wages by the size of firm

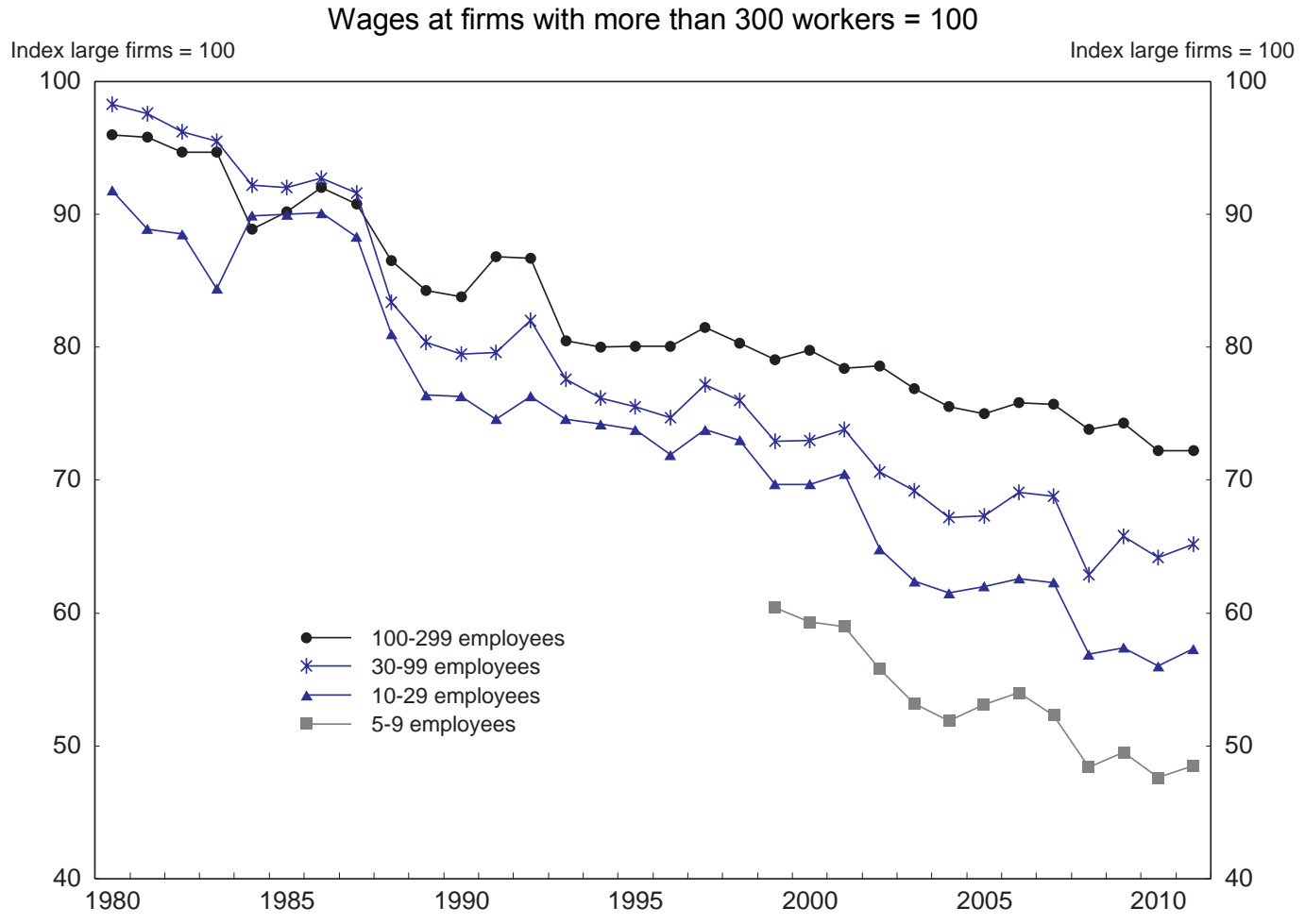

Source: Statistics Korea. 
ECO/WKP(2012)40

Table 12. Incidence of low wages by firm size in 20061

\begin{tabular}{lrrrrrrrrr}
\hline $\begin{array}{l}\text { Firm size } \\
\text { (number of workers) }\end{array}$ & $1-4$ & $5-9$ & $10-29$ & $30-49$ & $50-99$ & $100-299$ & $300-499$ & $500-999$ & $\begin{array}{c}1000 \\
\text { and up }\end{array}$ \\
\hline Male & 18.8 & 7.5 & 5.2 & 3.5 & 3.3 & 2.3 & 1.8 & 1.8 & 0.7 \\
Female & 39.1 & 22.5 & 18.9 & 14.1 & 12.8 & 11.6 & 9.9 & 9.5 & 4.0 \\
\hline
\end{tabular}

1. Low wage refers to wages below $50 \%$ of the median wage.

Source: Koh (2011).

\section{Conclusion}

71. Many of the policy recommendations, which are summarised in Box 2, would provide a double dividend in terms of boosting economic growth and fostering social cohesion. Recent OECD research shows that policies that reduce labour market dualism and improve access to education reduce income inequality while boosting economic growth (OECD, 2012). Moreover, these policies are important to mitigate the negative impact on equality from shifting the tax mix away from direct taxes on labour and corporate income towards consumption and property taxes. Policies to promote inclusive growth are a priority to reverse the rise in inequality and enhance social cohesion. Such measures should be carefully targeted so as to help maintain Korea's sound fiscal position and limit any negative impact on growth.

\section{Box 2. Summary of recommendations to promote social cohesion}

\section{Well-targeted increases in social spending to address inequality and poverty}

- Relax the eligibility conditions for the Basic Livelihood Security Programme and ensure adequate funding, while improving the work incentives of recipients.

- Expand the earned income tax credit by relaxing the eligibility conditions and aiming, in the long run, to include the self-employed.

- $\quad$ Target the Basic Old-Age Pension System on low-income elderly and increase the amount of the benefit, while promoting private savings for retirement by accelerating the introduction of company pensions.

- Ensure that National Health Insurance meets its goal of universal coverage and further lower the ceiling on copayments to provide adequate care to low-income households and persons with chronic health problems.

- Gradually expand long-term care services by emphasising home-based care to contain cost increases, while enhancing their quality.

\section{Labour market reforms to reduce labour market dualism}

- $\quad$ Reduce employment protection in practice for regular workers so that firms can realise adequate employment flexibility without relying as much on non-regular workers.

- Expand the coverage of non-regular workers by workplace-based social insurance systems, notably by improving compliance, to improve their welfare and reduce the cost advantages of non-regular workers.

- Increase training and career consultation to enhance employability of non-regular workers and their transition to regular employment.

- Revise the 2007 non-regular worker law, which is increasing employment instability and leading to a concentration of non-regular workers in more vulnerable types of employment, by extending the time limit on fixed-term contracts.

- Relax regulations on temporary agency workers by moving from a positive-list system to a negative list.

\section{Education reforms to promote equality}

- Enhance the access of disadvantaged children to high-quality ECEC by increasing tuition subsidies for low-income children.

- Increase the capacity of public kindergartens by including them in primary schools. 


\section{$\mathrm{ECO} / \mathrm{WKP}(2012) 40$}

- Develop the "admissions officer" system for universities to reduce the importance of the CSAT exam, thereby diminishing the role of hagwons.

- $\quad$ Reduce dependence on private tutoring, including hagwons, by improving the quality and diversity of secondary schools and strengthening vocational education and career guidance.

- Improve access to after-school tutoring by further expanding Internet and broadcast teaching systems and increasing the after-school programmes in schools.

- Expand student loans through the new programme that makes repayment contingent on income after graduation. 


\section{Bibliography}

Adema, W., P. Fron and M. Ladaique (2011), "Is the European Welfare State Really More Expensive?: Indicators on Social Spending, 1980-2012; and a Manual to the OECD Social Expenditure Database (SOCX)", OECD Social, Employment and Migration Working Papers, No. 124, OECD, Paris.

Alesina, A. and D. Rodrik (1994), "Distributive Politics and Economic Growth", The Quarterly Journal of Economics, Vol. 109.

An, C. and B. Bosworth (2011), "Income Inequality in Korea: An Analysis of Trends, Causes and Answers", Presentation at the Conference in Commemoration of KDI's $40^{\text {th }}$ Anniversary, 25 October, Seoul.

Bae, J. (2011), "Korean National Pensions: Facts and Functions in 2009", in Economic Crisis and Social Integration, Vol. 1, edited by Y. Kim and G. Széll, Peter Lang, Frankfurt.

Bassanini, A., J. Rasmussen and S. Scarpetta (1999), "The Economic Effects of Employment-Conditional Income Support Schemes for the Low-Paid: An Illustration from a CGE Model Applied to Four OECD Countries", OECD Economics Department Working Papers, No. 224, OECD, Paris.

Bray, M. (2009), Confronting the Shadow Education System, International Institute for Educational Planning, UNESCO, Paris.

Chang, S. (2009), "A Cultural and Philosophical Perspective on Korea's Education Reform: A Critical Way to Maintain Korea's Economic Momentum", Academic Paper Series on Korea, Korea Economic Institute, Washington, DC.

Chang, J. (2011), "Labor Market Dualism and Social Insurance Coverage in Korea", paper presented at a conference, "Welfare States' Response to Labor Market Dualism and The Working Poor", 11 December, Seoul.

Child Research Net (2010), 2010 Report on Children: Questionnaire Survey on Children's Daily Lives and Parent's Child-rearing in Five East Asian Cities.

Choi, S., S. Kim and R. Freeman (2012), Hard Work and Human Capital: Korea in the New Global Economy, Korea Development Institute, Seoul (forthcoming).

Chung, B. (2002), “Korea's War on Private Tutoring”, Paper presented at The Second International Forum on Education Reform, 2-5 September, Bangkok.

Chung, H. (2008), "Follow-up to the Non-Regular Work Law and Related Key Programs in 2008", Ministry of Employment and Labour.

Hwang, D. (2011), "Evaluation and Policy Implications of Making Work Pay Schemes in Korea”, Labor Issues in Korea 2010, edited by K. Bae, Korea Labor Institute, Seoul.

Joumard, I., M. Pisu and D. Bloch (2012), "Less Income Inequality and More Growth - Are They Compatible?: Part 3. Income Redistribution via Taxes and Transfers Across OECD Countries", OECD Economics Department Working Papers, No. 926, OECD, Paris.

Kahn, L. (2010), "Labor Market Policy: A Comparative View on the Costs and Benefits of Labor Market Flexibility”, CESIFO Working Papers, No. 3140.

Kang, B. and M. Yun (2008), "Changes in Korean Wage Inequality, 1980-2005”, IZA Discussion Paper, No. 3780 .

Kim, H. (2010), "The Achievement and Development of After-school Activities", Early Childhood Care and Education in Korea, Vol IX, Korea Educational Development Institute, Seoul. 
Kim, M. (2003), "Teaching and Learning in Korean Classrooms: The Crisis and the New Approach", Asia Pacific Education Review, Vol. 4.

Kim, S. and J. Lee (2003), “The Secondary School Equalization Policy in South Korea”, mimeo.

Kim, Y. (2009), "Research on Labour Mobility of Non-Regular Workers", Chapter 5 in Korea Development Institute Research Papers, No. 2009-03, Seoul.

Kim, J., R. Hwang and K. Kim (2011), "The Current Status of the Health Insurance and Tasks Ahead", in Economic Crisis and Social Integration, Vol. 1, edited by Y. Kim and G. Széll, Peter Lang, Frankfurt.

Kim, J, (2010), “A Comparison of Non-Regular Employment in Korea and Japan: Nature, Difference, and its Possible Reasons", Evolutionary and Institutional Economics Review, No. 6 (2).

Koh, Y., S. Kim, C. Kim, Y. Lee, J. Kim, S. Lee and Y. Kim (2010), "Social Policy", in The Korean Economy: Six Decades of Growth and Development, edited by I. SaKong and Y. Koh, Korea Development Institute, Seoul.

Koh, Y. (2011), "Social Safety Net in Korea: From Welfare to Workfare", Korea Development Institute, mimeo, Seoul.

Korea Development Institute (KDI) (2009), Study on Non-regular workers, Seoul (in Korean).

Korea Educational Development Institute (KEDI) (2006), OECD Thematic Review of Tertiary Education: Country Background Report for Korea, Seoul.

Korea Employers Federation (2006), 2006 Industrial Relations and Labor Market of Korea, Seoul.

Korea Employers Federation (2011), 2011 Industrial Relations and Labor Market of Korea, Seoul.

Korea International Labour Foundation (2011), “Government's Initiative to Improve Employment of Nonregular Workers in Public Sector", Labor Today, 12 December.

Korea Labor Review (various issues), Korea International Labour Foundation, Seoul.

Koske, I., J.-H. Fournier and I. Wanner (2011), "Less Income Inequality and More Growth - Are They Compatible?: Part 2. The Distribution of Labour Incomes", OECD Economics Department Working Papers, No. 925, OECD, Paris.

Kwon, H. (2010), “Temp-to-Perm Transition? Recent Legislation on Fixed-Term Employment and Firm's Choice", Labor Issues in Korea 2009, edited by M. Jun, Korea Labor Institute, Seoul.

Kwon, S. (2009), “Thirty Years of National Health Insurance in South Korea: Lessons for Achieving Universal Care Coverage", Health Policy and Planning, Vol. 24.

Lee, Y., M. Moon, M. Kim and S. Yang (2009), "A Survey on the Current Status of Hakwons (private academies) for Young Children in Korea", Research Project-05, Korea Institute of Child Care and Education, Seoul.

Lee, B. (2011), "Labor-market Characteristics and Poverty Dynamics of the Working Poor in Korea", Labor Issues in Korea 2010, edited by K. Bae, Korea Labor Institute, Seoul.

Ministry of Education (2000), Report on Private Tutoring, Seoul.

Ministry of Education, Science and Technology (MEST) (2011), Analysis of the Results of the 2010 Survey on Private Education Costs, Seoul (in Korean).

National Health Insurance Corporation (2009), National Health Insurance System of Korea, Seoul.

No, D. et al. (2009), "Study on the Reform of Activation Policies in Korea", Korea Institute for Health and Social Affairs, Seoul (in Korean). 
OECD (2000), OECD Economic Survey of Korea, OECD, Paris.

OECD (2006), Employment Outlook, OECD, Paris.

OECD (2007), OECD Economic Survey of Korea, OECD, Paris.

OECD (2008), OECD Economic Survey of Korea, OECD, Paris.

OECD (2009), OECD Reviews of Tertiary Education: Korea, OECD, Paris.

OECD (2010a), Economic Policy Reforms: Going for Growth, OECD, Paris.

OECD (2010b), OECD Economic Survey of Korea, OECD, Paris.

OECD (2010c), PISA 2009 Results: What Students Know and Can Do, Volume I, OECD, Paris.

OECD (2011a), A Framework for Growth and Social Cohesion in Korea, OECD, Paris.

OECD (2011b), Divided We Stand: Why Inequality Keeps Rising, OECD, Paris.

OECD (2011c), OECD Education at a Glance 2011, OECD, Paris.

OECD (2011d), Pensions at a Glance 2011: Retirement-income Systems in OECD and G20 Countries, OECD, Paris.

OECD (2011e), PISA in Focus: Does Investing in After-School Classes Pay Off?, OECD, Paris.

OECD (2012), Going for Growth, OECD, Paris.

Pearson, M. and S. Scarpetta (2000), "An Overview: What Do We Know About Policies to Make Work Pay?”, OECD Economic Studies, Vol. 31, OECD, Paris.

Rhee, O., E. Kim, N. Shin and M. Moon (2008), "Developing Models to Integrate Early Childhood Education and Childcare in Korea", International Journal of Child Care and Education Policy, Vol. 2, No. 1.

Sakong, Il (1993), Korea in the World Economy, Institute for International Economics, Washington, DC.

Sorensen, C. (1994), "Success and Education in South Korea", Comparative Education, Vol. 38, No. 1.

Stiglitz, J., A. Sen and J. Fitoussi (2009), Report by the Commission on the Measurement of Economic Performance and Social Progress.

Suh, M. and E. Kim (2010), Early Childhood Education and Care Policy in Korea, Korea Institute of Child Care and Education, Seoul.

Ventura, A. and S. Jang (2010), "Private Tutoring through the Internet: Globalization and Offshoring", Asia Pacific Education Review, Vol. 11.

Won, C., H. Shin, M. Yoon, M. Kim, J. Kang and K. Nam (2011), Long-term Projections of Social Expenditure, Korea Institute of Health and Social Affairs, Seoul (in Korean).

Yoo, H., M. Lee, M. Chang, E. Kim, E. Kim and S. Song (2008), "Developing Ways of Cooperation and Integration of Kindergartens and Child Care Centers", Research Project-08, Korea Institute of Child Care and Education, Seoul.

Yoon, H. (2011), "Structural Changes in the Korean Economy Since the 1990s", KDI Focus, Korea Development Institute, Seoul (in Korean).

Yun, E. (2009), "Places for Educating and Caring for Young Children in Korea: Where are our Children Edu-cared?", Child Research Net. 


\section{WORKING PAPERS}

The full series of Economics Department Working Papers can be consulted at www.oecd.org/eco/workingpapers/

962. Housing price and investment dynamics in Finland

(May 2012) by Christophe André and Clara Garcia

961. Improving health outcomes and system in Hungary

(May 2012) by Mehmet Eris

960. Towards a more inclusive labour market in Hungary

(May 2012) by Rafał Kierzenkowski

959. Ensuring stability and efficiency of the Hungarian financial sector

(May 2012) by Olena Havrylchyk

958. Ensuring debt sustainability amid strong economic uncertainty in Hungary

(June 2012) by Pierre Beynet and Rafał Kierzenkowski

957. Improving the health-care system in Poland

(April 2012) by Hervé Boulhol, Agnieszka Sowa and Stanislawa Golinowska

956. Options for benchmarking infrastructure performance

(April 2012) by Mauro Pisu, Peter Hoeller and Isabelle Joumard

955. Greenhouse gas emissions and price elasticities of transport fuel demand in Belgium

(April 2012) by Tom Schmitz

954. Bringing Belgian public finances to a sustainable path

(April 2012) by Tomasz Koźluk, Alain Jousten and Jens Høj

953. Climate change policies in Poland - minimising abatement costs

(April 2012) by Balázs Égert

952. Income inequality in the European Union

(April 2012) by Kaja Bonesmo Fredriksen

951. Reducing poverty in Chile: cash transfers and better jobs

(April 2012) by Nicola Brandt

950. Tax reform in Norway: A focus on capital taxation

(April 2012) by Oliver Denk

949. The short-term effects of structural reforms: an empirical analysis

(March 2012) by Romain Bouis, Orsetta Causa, Lilas Demmou, Romain Duval and

Aleksandra Zdzienicka

948. Short-term gain or pain? A DSGE model-based analysis of the short-term effects of structural reforms in labour and product markets

(March 2012) by Matteo Cacciatore, Romain Duval and Giuseppe Fiori 
947. Do house prices impact consumption and interest rate?: Evidence from OECD countries using an agnostic identification procedure

(March 2012) by Christophe André, Rangan Gupta and Patrick T. Kanda

946. Assessing the sensitivity of Hungarian debt sustainability to macroeconomic shocks under two fiscal policy reactions

(March 2012) by Pierre Beynet and Edouard Paviot

945. Non-Keynesian effects of fiscal consolidation: an analysis with an estimated DSGE Model for the Hungarian economy

(March 2012) by Szilárd Benk and Zoltán M. Jakab

944. Work incentives and recent reforms of the tax and benefit system in Hungary

(March 2012) by Tímea Ladányi and Rafal Kierzenkowski

943. Building blocks for a better functioning housing market in Chile

(February 2012) by Aida Caldera Sánchez

942. The impact of changes in second pension pillars on public finances in Central and Eastern Europe (January 2012) by Balász Égert

941. Improving energy system efficiency in the Czech Republic (January 2012) by Artur Radziwill

940. Structural change and the current account: the case of Germany (January 2012) by Fabrizio Coricelli and Andreas Wörgötter

939. Reforming education in England

(January 2012) by Henrik Braconier

938. The nature of financial and real business cycles: The great moderation and banking sector procyclicality

(January 2012) by Balázs Égert and Douglas Sutherland

937. Fiscal consolidation

Part 6. What are the best policy instruments for fiscal consolidation?

(January 2012) by Robert P. Hagemann

936. Fiscal consolidation

Part 5. What factors determine the success of consolidation efforts?

(January 2012) by Margit Molnar

935. Fiscal consolidation

Part 4. Case studies of large fiscal consolidation episodes

(January 2012) by Hansjörg Blöchliger, Dae-Ho Song and Douglas Sutherland

934. Fiscal consolidation

Part 3. Long-run projections and fiscal gap calculations

(January 2012) by Rossana Merola and Douglas Sutherland 